\title{
Nitrous acid (HONO) emissions under real-world driving conditions from vehicles in a UK road tunnel
}

\author{
Louisa J. Kramer ${ }^{1}$, Leigh R. Crilley ${ }^{1, a}$, Thomas J. Adams ${ }^{2, b}$, Stephen M. Ball ${ }^{2}$, Francis D. Pope ${ }^{1}$, and William J. Bloss ${ }^{1}$ \\ ${ }^{1}$ School of Geography, Earth and Environmental Sciences, University of Birmingham, Birmingham, UK \\ ${ }^{2}$ School of Chemistry, University of Leicester, Leicester, UK \\ ${ }^{a}$ now at: Department of Chemistry, York University, Toronto, ON, Canada \\ b now at: Ricardo Energy \& Environment, Harwell, Oxon, UK
}

Correspondence: Louisa J. Kramer (1.kramer@bham.ac.uk)

Received: 20 November 2019 - Discussion started: 3 December 2019

Revised: 15 March 2020 - Accepted: 20 March 2020 - Published: 5 May 2020

\begin{abstract}
Measurements of atmospheric boundary layer nitrous acid (HONO) and nitrogen oxides $\left(\mathrm{NO}_{x}\right)$ were performed in summer 2016 inside a city centre road tunnel in Birmingham, United Kingdom. HONO and $\mathrm{NO}_{x}$ mixing ratios were strongly correlated with traffic density, with peak levels observed during the early evening rush hour as a result of traffic congestion in the tunnel. A day-time $\Delta \mathrm{HONO} / \Delta \mathrm{NO}_{x}$ ratio of $0.85 \%(0.72 \%$ to $1.01 \%, 95 \%$ confidence interval) was calculated using reduced major axis regression for the overall fleet average (comprising 59\% diesel-fuelled vehicles). A comparison with previous tunnel studies and analysis on the composition of the fleet suggest that goods vehicles have a large impact on the overall HONO vehicle emissions; however, new technologies aimed at reducing exhaust emissions, particularly for diesel vehicles, may have reduced the overall direct HONO emission in the UK. This result suggests that in order to accurately represent urban atmospheric emissions and the $\mathrm{OH}$ radical budget, fleet-weighted $\mathrm{HONO} / \mathrm{NO}_{x}$ ratios may better quantify HONO vehicle emissions in models, compared with the use of a single emissions ratio for all vehicles. The contribution of the direct vehicular source of HONO to total ambient HONO concentrations is also investigated and results show that, in areas with high traffic density, vehicle exhaust emissions are likely to be the dominant HONO source to the boundary layer.
\end{abstract}

\section{Introduction}

Nitrous acid (HONO) is an important atmospheric constituent in the boundary layer, as its photolysis leads to the formation of $\mathrm{OH}$ radicals (Reaction R1), which drive atmospheric oxidation reactions, pollutant removal and the formation of secondary species. This is particularly important in urban areas where the measured HONO mixing ratios can reach up to parts per billion, and HONO photolysis can be the dominant $\mathrm{HO}_{x}$ source (Alicke et al., 2002; Elshorbany et al., 2009; Kleffmann, 2007; Lee et al., 2016; Michoud et al., 2012; Villena et al., 2011).

$\mathrm{HONO}+h v \stackrel{\lambda<400 \mathrm{~nm}}{\longrightarrow} \mathrm{OH}+\mathrm{NO}$

The sources of HONO in the atmosphere can be primary or secondary (Fig. 1). Primary sources include direct emissions from combustion processes such as vehicle emissions (Kirchstetter et al., 1996; Liu et al., 2017; Rappenglück et al., 2013; Trinh et al., 2017; Xu et al., 2015), soil microbial activity (Laufs et al., 2017; Maljanen et al., 2013; Meusel et al., 2018; Oswald et al., 2013; Su et al., 2011) and biocrusts (Maier et al., 2018; Meusel et al., 2018; Weber et al., 2015). Secondary sources were thought to be dominated by the homogeneous gas phase reaction of $\mathrm{NO}$ and $\mathrm{OH}$ during the day (resulting in a null cycle with Reaction R1), and the heterogeneous production of $\mathrm{HONO}$ from $\mathrm{NO}_{2}$ on surfaces at night (Calvert et al., 1994; Finlayson-Pitts et al., 2003; Jenkin et al., 1988; Kleffmann et al., 1998; Stutz et al., 2002). More recently, studies have shown that heterogeneous reactions are also important sources of HONO during the day and include photo- 


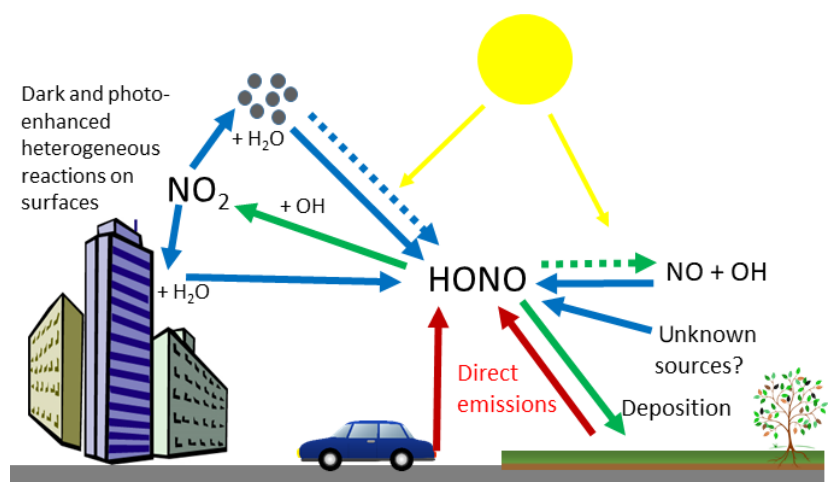

Figure 1. Sources and sinks of HONO in the troposphere, showing direct emission (red arrows), secondary sources (blue arrows) and HONO sinks (green arrows). Dashed arrows represent solar driven reactions.

enhanced reduction of $\mathrm{NO}_{2}$ on organic substrates (George et al., 2005; Monge et al., 2010; Stemmler et al., 2006) and nitrate photolysis (Reed et al., 2017; Ye et al., 2017; Zhou et al., 2011). Despite numerous studies over the last few decades, substantial uncertainties remain regarding the relative magnitude of these sources, with models frequently unable to account for total measured HONO concentrations without the inclusion of unknown sources, typically driven by photolysis (Huang et al., 2017; Lee et al., 2016; Michoud et al., 2014; Vandenboer et al., 2014; Vogel et al., 2003; Wang et al., 2017). A photo-stationary steady-state method based on measurements of $\mathrm{HONO}, \mathrm{OH}$ and $\mathrm{NO}_{x}$ has previously been used to infer missing HONO sources; however, in areas of high spatial heterogeneity this method breaks down because the lifetime of $\mathrm{HONO}$ is much longer than that of $\mathrm{OH}$, or of $\mathrm{NO}$ (with respect to $\mathrm{NO}_{x}-\mathrm{O}_{3}$ equilibrium) (Crilley et al., 2016; Lee et al., 2013).

In areas with high traffic density, HONO emitted directly from vehicle exhausts is an important source, as indicated by large peaks in ambient HONO concentrations observed during rush hour periods (e.g. Qin et al., 2009; Rappenglück et al., 2013; Stutz et al., 2004; Tong et al., 2016; Wang et al., 2017; $\mathrm{Xu}$ et al., 2015). Tong et al. (2016) estimated that direct emissions from vehicles at an urban site in Beijing contributed $48.8 \%$ of the total measured HONO, almost 5 times higher than the contribution at a suburban site (10.3\%) located $50 \mathrm{~km}$ north-east of Beijing city centre.

A HONO/ $\mathrm{NO}_{x}$ emission ratio is often used to parameterize the HONO contribution from vehicles. Various studies have determined this ratio either directly via chassis dynamometers (Calvert et al., 1994; Liu et al., 2017; Nakashima and Kajii, 2017; Pitts et al., 1984; Trinh et al., 2017) or from ambient roadside and tunnel measurements (Kirchstetter et al., 1996; Kurtenbach et al., 2001; Liang et al., 2017; Rappenglück et al., 2013; Yang et al., 2014). Chassis dynamometer studies benefit from the direct quantification of HONO from vehicle exhausts under different driv- ing cycles; however, the number of vehicles tested in these studies is very limited and may not be representative of the wider fleet or real-world operational conditions. Both tunnel and ambient roadside measurements on the other hand allow for analysis of HONO emissions from a larger vehicle fleet, under real-world driving conditions. Tunnel studies have the additional benefits of eliminating photolytic loss and photoenhanced surface sources of HONO and of reducing dispersion. However, care must be taken to accurately correct for background levels of HONO at the tunnel entrance and for other HONO sources, such as heterogeneous reactions on tunnel walls and emitted particles.

Reports of the $\mathrm{HONO} / \mathrm{NO}_{x}$ emission ratio from chassis dynamometer and ambient roadside and tunnel studies are highly variable, ranging between $0.03 \%$ and $2.1 \%$, depending on fuel type and implementation of technologies aimed at reducing emissions, such as diesel oxidation catalysts (DOCs) and diesel particulate filters (DPFs). An emission ratio of $0.8 \%$ is widely used in modelling studies, which is based on a tunnel study with a fleet comprising primarily gasoline vehicles $(\sim 75 \%)$ conducted in 19971998 (Kurtenbach et al., 2001). However, a recent chassis dynamometer study by Trinh et al. (2017) showed that $\mathrm{HONO} / \mathrm{NO}_{x}$ ratios were higher from diesel vehicles (ranging from $0.16 \%$ to $1.00 \%$ ) compared to petrol vehicles ( $0 \%$ to $0.95 \%)$, under most driving conditions. The higher $\mathrm{HONO} / \mathrm{NO}_{x}$ ratio observed from diesel vehicle exhausts is thought to be due to a reduction-oxidation reaction, as proposed by Ammann et al. (1998) and Gerecke et al. (1998), in which $\mathrm{NO}_{2}$ can be converted heterogeneously to HONO on soot via Reaction (R2).

$\mathrm{NO}_{2}+[\mathrm{C}-\mathrm{H}]_{\mathrm{red}} \rightarrow \mathrm{HONO}+[\mathrm{C}]_{\mathrm{ox}}$,

where $[\mathrm{C}-\mathrm{H}]_{\text {red }}$ is a surface site on the soot particle.

A number of laboratory studies have supported this reaction, with HONO yields varying between $20 \%$ and $100 \%$ depending on the fuel type used to generate the soot, initial $\mathrm{NO}_{2}$ concentrations and soot coatings (Arens et al., 2001; Aubin and Abbatt, 2007; Gerecke et al., 1998; Guan et al., 2017; Khalizov et al., 2010; Kleffmann et al., 1999; Lelièvre et al., 2004; Romanias et al., 2013; Stadler and Rossi, 2000). An observation that is consistent across many laboratory experiments is that the uptake of $\mathrm{NO}_{2}$ decreases over time, which has previously been attributed to the deactivation of soot surface receptor sites (Kalberer et al., 1999). Lelièvre et al. (2004) observed complete deactivation after the soot was exposed to ambient outdoor conditions for approximately $20 \mathrm{~h}$. As a result of the soot surface deactivation, Reaction (R2) is not expected to have a large impact on atmospheric HONO levels once soot has been exhausted from the vehicle. However, Khalizov et al. (2010) found that if soot was pre-heated up to $300^{\circ} \mathrm{C}$, the $\mathrm{HONO}$ yield increases, as a result of the removal of products from incomplete combustion, allowing for a greater number of reactive sites to reduce $\mathrm{NO}_{2}$ to HONO. Reactions within the vehicle exhaust 
pipe, on fresh soot, may still be a potential source of HONO from vehicles. Determining the magnitude of this source under real-world conditions, however, is challenging. Two recent studies in Hong Kong investigated the relationship between soot and HONO directly emitted from vehicles, with contrasting results. Xu et al. (2015) found a strong positive correlation $\left(R^{2}=0.83\right)$ between $\mathrm{HONO} / \mathrm{NO}_{x}$ and black carbon (BC) in fresh traffic plumes sampled at an ambient air monitoring site, but no correlation was ascertained in a separate road tunnel experiment by Liang et al. (2017). Data taken at a site in North Kensington, London, during 2012 as part of the Clean Air for London (ClearfLo) project (Bohnenstengel et al., 2015) show a modest correlation between HONO and $\mathrm{BC}\left(R^{2}=0.71\right)$; however, there is no clear correlation between $\mathrm{HONO} / \mathrm{NO}_{x}$ and $\mathrm{BC}$ when sampling fresh pollution plumes (i.e. when $\mathrm{NO} / \mathrm{NO}_{x}$ ratios are large) (see Fig. S1 in the Supplement). This agrees with the results of Liang et al. (2017), who suggested that $\mathrm{HONO}$ formed via $\mathrm{NO}_{2}$ conversion on BC may be insignificant even in a road tunnel scenario shortly after emission.

The primary aim of this study is to determine $\mathrm{HONO} / \mathrm{NO}_{x}$ emission ratios under real-world driving conditions, with a fleet containing a high proportion of diesel vehicles. In the UK, at the end of 2016, there were over 38 million vehicles licensed for use on the roads (DfT, 2017). The majority of vehicles were passenger cars $(\sim 83 \%)$ and goods vehicles $(11.4 \%)$, with the remainder consisting of motorcycles, buses/coaches and other vehicles (e.g. agricultural machines, ambulances). Diesel-fuelled cars and goods vehicles, in total, account for $44 \%$ of the vehicles on the road in the UK in 2016 (data on the statistics discussed here can be found in Table S1 in the Supplement). To our knowledge this is the first study of direct HONO exhaust emissions performed in the UK and the first study in any country that has a diesel composition greater than $40 \%$ of the vehicle fleet. Using co-located $\mathrm{HONO}, \mathrm{NO}_{x}$ and $\mathrm{CO}_{2}$ data, we investigated the $\mathrm{HONO} / \mathrm{NO}_{x}$ ratio using measurements taken in a roadtunnel in the city centre of Birmingham and considered the impact of new technologies implemented in the European emission standards on the measured HONO emissions. Finally, the contribution of direct $\mathrm{HONO}$ emissions to the total HONO measured in an urban area was determined.

Statistical analysis was conducted in $\mathrm{R}$, version 3.6.1 ( $\mathrm{R}$ Core Team, 2019), using the openair package (Carslaw and Ropkins, 2012), and the lmodel 2 package (Legendre, 2018) for the reduced-major-axis (RMA) regression. Figures were produced using the packages ggplot2 (Wickham, 2016) and leaflet (Cheng et al., 2019).

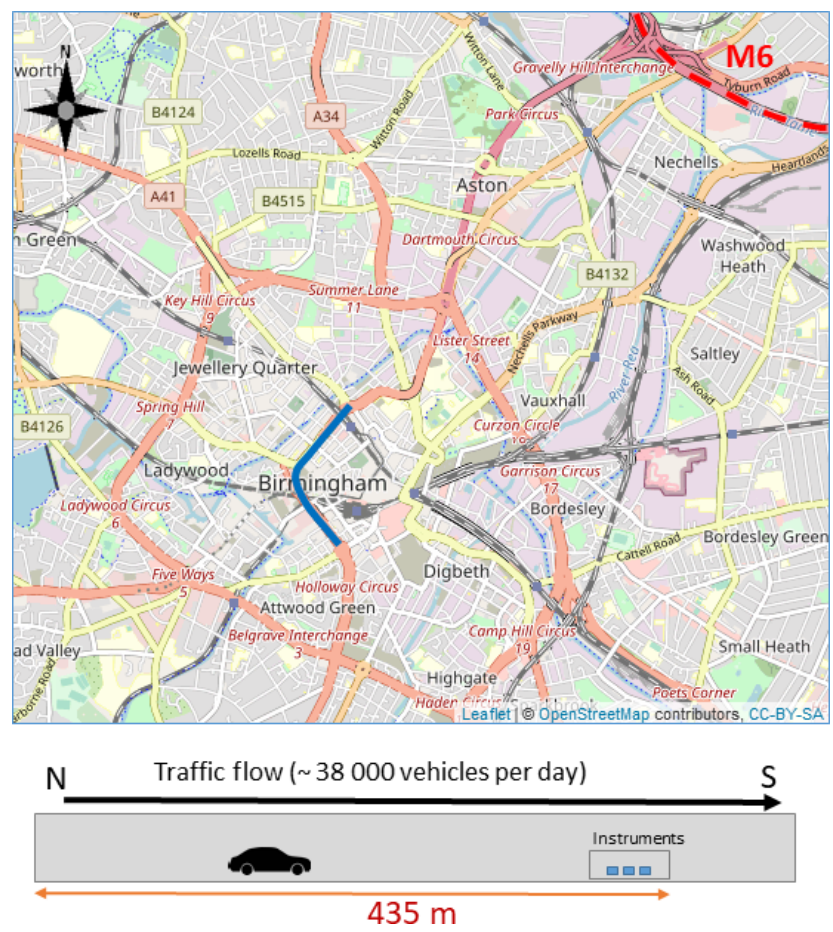

Figure 2. Map of Birmingham City Centre showing the M6 motorway (red dashed line) and schematic of the Queensway Tunnel (highlighted in blue on the map). (C) OpenStreetMap contributors 2019. Distributed under a Creative Commons BY-SA License.

\section{Experimental}

\subsection{Queensway Tunnel}

Measurements took place in the southbound bore of the Queensway Tunnel (Fig. 2), a two-bore, twin lane tunnel, $548 \mathrm{~m}$ in length, located in the centre of Birmingham, UK $\left(52^{\circ} 28^{\prime} 46^{\prime \prime} \mathrm{N}, 1^{\circ} 54^{\prime} 20^{\prime \prime} \mathrm{W}\right)$. The tunnel forms part of the A38 roadway which is a major route into and out of Birmingham City Centre, and links to the M6 motorway north of the city. The instruments were located at the distant end of a maintenance area approximately $435 \mathrm{~m}$ from the entrance to the southbound tunnel. The two bores of the tunnel are separated by a solid wall eliminating any influence in the measurements from vehicles travelling in the northbound bore. The tunnel was not mechanically ventilated during the measurement period. Airflow through the tunnel is therefore via natural wind flow or induced by vehicle movement (piston effect). The average speed of vehicles through the tunnel during the day-time (06:00 to 19:59 British Summer Time, BST) is $52 \mathrm{~km} \mathrm{~h}^{-1}$ (33 miles per hour, mph) which drops to $33 \mathrm{~km} \mathrm{~h}^{-1}(21 \mathrm{mph})$ at 17:00 during peak evening rush hour as a result of congestion (see Fig. S2). 


\subsection{Fleet information}

Data from an Automatic Number Plate Recognition (ANPR) camera commissioned by Birmingham City Council were used to obtain information on the vehicle fleet passing through the tunnel. ANPR data were taken from 8 to 11 November 2016 and included vehicle type, European emissions standard and capture rate of the vehicle number plates, on a $15 \mathrm{~min}$ timescale. The ANPR capture rate is based on a comparison of manual classified counts (MCC) with the ANPR data. The capture rate was typically around $90 \%$ of MCC, with counts missing from ANPR usually as a result of the number plate being obscured (Rhead et al., 2012). We assumed the same fleet proportions for the missing vehicle counts and adjusted the final data accordingly. Figure 3 shows the mean hourly number of vehicles travelling through the tunnel during the weekdays and a breakdown of vehicles by type. The ANPR data were also compared to manual traffic counts performed at the exit of the southbound tunnel on selected days during the measurement period with good agreement. Approximately 37700 vehicles travel through the southbound bore of the Queensway tunnel during an average weekday. The majority of these vehicles are petrol $(40 \%)$ and diesel $(44 \%)$ fuelled passenger cars, with the remaining fleet comprised primarily of dieselfuelled light-goods vehicles (LGVs, e.g. vans, small pickups) $(10.4 \%)$, ordinary goods vehicles (OGVs, e.g. trucks, articulated vehicles) $(2.5 \%)$ and passenger vehicles (taxis and buses) (1.3\%).

\subsection{Instrumental techniques}

The instruments were installed in the tunnel in close proximity $(1.5 \mathrm{~m})$ to the roadside and made measurements from 29 July until 8 August 2016. Access to the instruments was only possible when the tunnel was closed to traffic during maintenance periods, which occurred approximately every 2 weeks. Table 1 provides an overview of the instrumentation deployed in the tunnel during the campaign.

Direct spectroscopic measurements of $\mathrm{HONO}$ and $\mathrm{NO}_{2}$ were made by broadband cavity enhanced absorption spectroscopy (BBCEAS) (Langridge et al., 2009; Thalman et al., 2015). The BBCEAS instrument operated in the wavelength range 363 to $388 \mathrm{~nm}$, which includes a highly structured part of the $\mathrm{NO}_{2}$ spectrum and two HONO absorption bands at 368 and $385 \mathrm{~nm}$. Ultraviolet light from an LED light source (LEDengin LZ1-10UV00, nominal peak wavelength $=365 \mathrm{~nm}$ ) was directed through a cavity formed by two highly reflective mirrors (Layertec $\mathrm{GmbH}, 25 \mathrm{~mm}$ diameter, $0.5 \mathrm{~m}$ radius of curvature, high reflectivity 370 to $395 \mathrm{~nm}$ ) separated by $80 \mathrm{~cm}$, giving an effective path length of approximately $1.4 \mathrm{~km}$. The mirrors were housed in bespoke mirror mounts $($ length $=11 \mathrm{~cm}$ ) which were purged with nitrogen ( $0.9 \mathrm{~L} \mathrm{~min}^{-1}$ divided between the two mounts), and thus BBCEAS data were corrected for the cavity's length factor $(L F=1.37)$. The cavity was operated "open path"; i.e. the portion of the cavity between the mirror mounts was open to the ambient atmosphere. This open-path configuration has the advantage that there were no wall losses or heterogeneous production of HONO within the instrument. A Teflon tube was inserted between the mirror mounts in order to measure the reference spectrum of light transmitted when the cavity was purged with nitrogen. The reflectivity of the cavity mirrors (as a function of wavelength) was characterized in the laboratory before the campaign; their measured reflectivity peaked at $99.940 \%$ at $387 \mathrm{~nm}$. The reflectivity was verified in the field by measuring the $380 \mathrm{~nm}$ absorption band of $\mathrm{O}_{4}$ when purging the cavity with pure oxygen, and measurements taken at the start and end of the campaign agreed to within $4.5 \%$.

BBCEAS spectra were integrated for $20 \mathrm{~s}$ (the average of two $10 \mathrm{~s}$ acquisitions) using an OceanOptics QEPro spectrometer (instrument line shape $=0.20 \mathrm{~nm}$ HWHM). Spectra were fitted with reference absorption cross sections for HONO (Stutz et al., 2000), $\mathrm{NO}_{2}$ (Vandaele et al., 1998) and $\mathrm{O}_{4}$ (Hermans as given in the HITRAN database, Richard et al., 2012), and any remaining unfitted broadband absorption was attributed to extinction by ambient aerosol particles. Typical statistical errors for retrieving $\mathrm{HONO}$ and $\mathrm{NO}_{2}$ concentrations from the spectral structure were \pm 0.8 and $\pm 0.9 \mathrm{ppbv},(1 \sigma$ in $20 \mathrm{~s})$ respectively. The BBCEAS measurements are also affected by systematic uncertainties in the molecules' reference absorption cross sections (typically $\pm 3 \%)$ and for determining the mirror reflectivity in the field $( \pm 4.5 \%)$. Extinction by ambient aerosol also reduced the effective path length of the BBCEAS measurement. HONO retrievals tended to be dominated by statistical (spectral fitting) errors, whereas retrievals of the much higher ambient $\mathrm{NO}_{2}$ concentrations were dominated by the systematic uncertainties in the cross sections and the mirror reflectivity. For the mean HONO (3 ppbv) and $\mathrm{NO}_{2}(75 \mathrm{ppbv})$ amounts recorded during the campaign, the total measurement uncertainties (from combining the statistical and systematic errors) were $\pm 1.2 \mathrm{ppbv}$ for $\mathrm{HONO}$ and $\pm 5 \mathrm{ppbv}$ for $\mathrm{NO}_{2}$.

$\mathrm{NO}$ was measured by a commercial chemiluminescence $\mathrm{NO}_{x}$ analyser (Thermo Environmental Instruments Inc: Model 42C). The detection limit of the $42 \mathrm{C}$ was determined from 3 times the standard deviation of the measurement in zero air and was calculated to be approximately $0.2 \mathrm{pbbv}$ for a $1 \mathrm{~min}$ averaging period. The uncertainty of the instrument was estimated to be $\pm 10 \%$ from calibrations. The analyser is capable of measuring $\mathrm{NO}_{2}$ and $\mathrm{NO}_{x}$. However, the instrument utilizes a molybdenum converter to covert $\mathrm{NO}_{2}$ to $\mathrm{NO}$, an approach which is known to be influenced by positive interference from other $\mathrm{NO}_{y}$ species such as $\mathrm{HONO}$, nitric acid $\left(\mathrm{HNO}_{3}\right)$, peroxyacetyl nitrate (PAN) and alkyl nitrates (e.g. Dunlea et al., 2007; Villena et al., 2012); therefore the final $\mathrm{NO}_{x}$ used in this study is calculated from the sum of the $\mathrm{NO}$ measured by the $42 \mathrm{C}$ and $\mathrm{NO}_{2}$ by the BBCEAS. The inlet for the $42 \mathrm{C}$ instrument was shared with a non- 

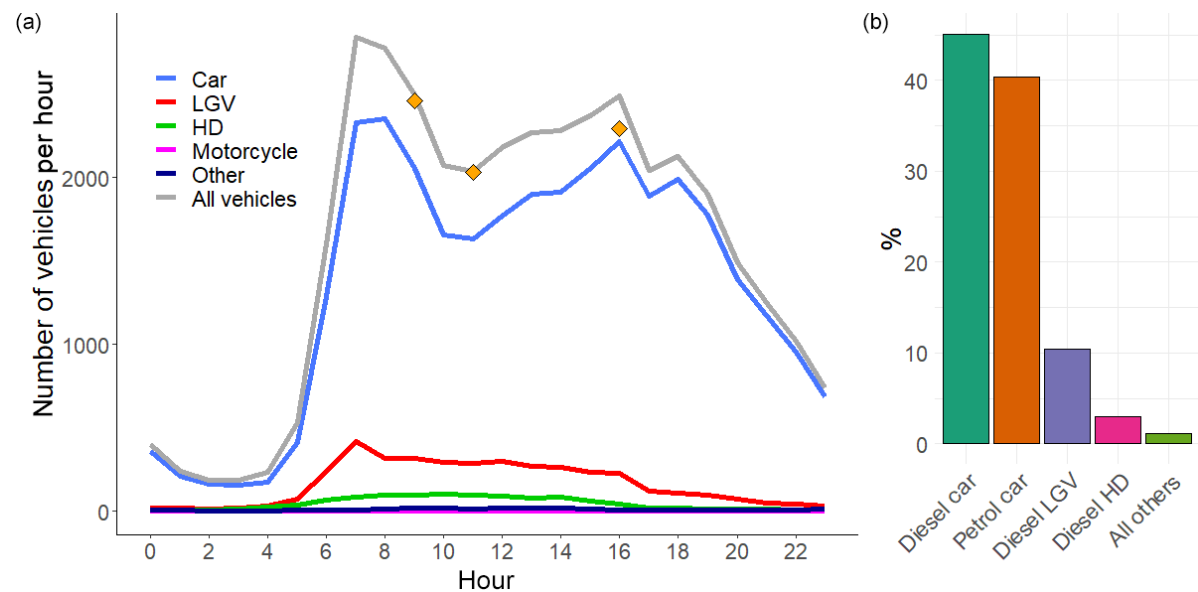

Figure 3. (a) Average hourly vehicle fleet in the southbound tunnel from the corrected ANPR counts for weekdays (LGV = light goods vehicles, $\mathrm{HD}=$ heavy-duty vehicles, e.g. trucks, lorries and buses). Orange points represent the counts estimated from video footage recorded during the measurement period. (b) Percentage of vehicle types, determined from all weekday ANPR data in November 2016.

Table 1. Overview of instruments deployed in the Queensway Tunnel.

\begin{tabular}{|c|c|c|c|c|}
\hline Instrument & Measurement & Method & $\begin{array}{l}\text { Sampling } \\
\text { time }(\mathrm{s})\end{array}$ & Uncertainty \\
\hline TEI: $42 \mathrm{c}$ & $\mathrm{NO}\left(\right.$ and $\mathrm{NO}_{y}$ ) & $\begin{array}{l}\text { Chemiluminescence } \\
\text { (Mo converter) }\end{array}$ & 60 & $\pm 10 \%$ \\
\hline $\begin{array}{l}\text { BBCEAS } \\
\text { (open-path) }\end{array}$ & $\mathrm{HONO}$ and $\mathrm{NO}_{2}$ & $\begin{array}{l}\text { Broadband cavity enhanced } \\
\text { absorption spectroscopy }\end{array}$ & 20 & $\begin{array}{l} \pm 5 \mathrm{ppbv}\left(\mathrm{NO}_{2}\right) \\
\pm 1.2 \mathrm{ppbv}(\mathrm{HONO})\end{array}$ \\
\hline $\begin{array}{l}\text { LI-COR: } \\
\text { LI-820 }\end{array}$ & $\mathrm{CO}_{2}$ & Non-dispersive infrared & 1 & $\pm 5 \%$ \\
\hline $\begin{array}{l}\text { Kestrel } 4500 \\
\text { anemometer }\end{array}$ & $\begin{array}{l}\text { Wind speed (WS), } \\
\text { temperature }(T), \\
\text { relative humidity }(\mathrm{RH})\end{array}$ & $\begin{array}{l}\text { Impeller (WS) } \\
\text { Solid state sensor }(T, \mathrm{RH})\end{array}$ & 600 & $\begin{array}{l}\text { The larger of } \pm 3 \% \text { or } 0.1 \mathrm{~m} \mathrm{~s}^{-1} \text { (WS) } \\
\pm 0.5^{\circ} \mathrm{C}, \pm 3 \% \text { RH units }\end{array}$ \\
\hline
\end{tabular}

dispersive infrared instrument (LI-COR: Model LI-820) to measure $\mathrm{CO}_{2}$. The LI-COR was calibrated with pure $\mathrm{N}_{2}$ ( 0 ppmv $\mathrm{CO}_{2}$ ) and 1500 ppmv $\mathrm{CO}_{2}$ to determine the relative uncertainty $( \pm 5 \%)$ and precision $(1.2 \%, 2 \sigma)$. The LI-COR and $42 \mathrm{C}$ analysers were evaluated for drift from zero measurements taken before and after the measurement campaign. The drift for $\mathrm{CO}_{2}$ and $\mathrm{NO}_{x}$ were determined to be $1.45 \mathrm{ppmv}$ and $0.42 \mathrm{ppbv}$, respectively. The drift for both instruments was less than $2 \%$ of the minimum measured values in the tunnel $\left(\mathrm{NO}=1.27 \%, \mathrm{CO}_{2}=0.35 \%\right)$, and therefore no correction was deemed necessary here. A mini-meteorological station anemometer (Kestrel 4500) was deployed near the top of the tunnel ( $3 \mathrm{~m}$ above ground level and $1 \mathrm{~m}$ from the roadside) to measure the temperature, relative humidity and air flow in the tunnel.

\section{Results and discussion}

\subsection{Data overview}

Figure 4 presents 15 min averaged time series for gases measured in the tunnel. $\mathrm{NO}, \mathrm{NO}_{2}, \mathrm{HONO}$ and $\mathrm{CO}_{2}$ follow the same diurnal cycle as each other, indicating that they have a similar source. There is a clear difference in weekday and weekend diurnal cycles, with peaks associated with rush hour traffic observed in $\mathrm{NO}, \mathrm{NO}_{2}, \mathrm{HONO}$ and $\mathrm{CO}_{2}$ during the weekdays, which are not present at the weekend. The measured concentrations are also lower at the weekend, on average. On weekdays, the mixing ratios of all gas species increase from around 06:00 (start of morning rush hour) and drop away in the afternoon. A large spike in the evening around 17:30 to 18:00 is observed, which coincides with congestion in the southbound tunnel during peak evening rush hour. The congestion is also evident in the lower mean vehicle speeds at 17:00 to 18:00 (Fig. S2). 

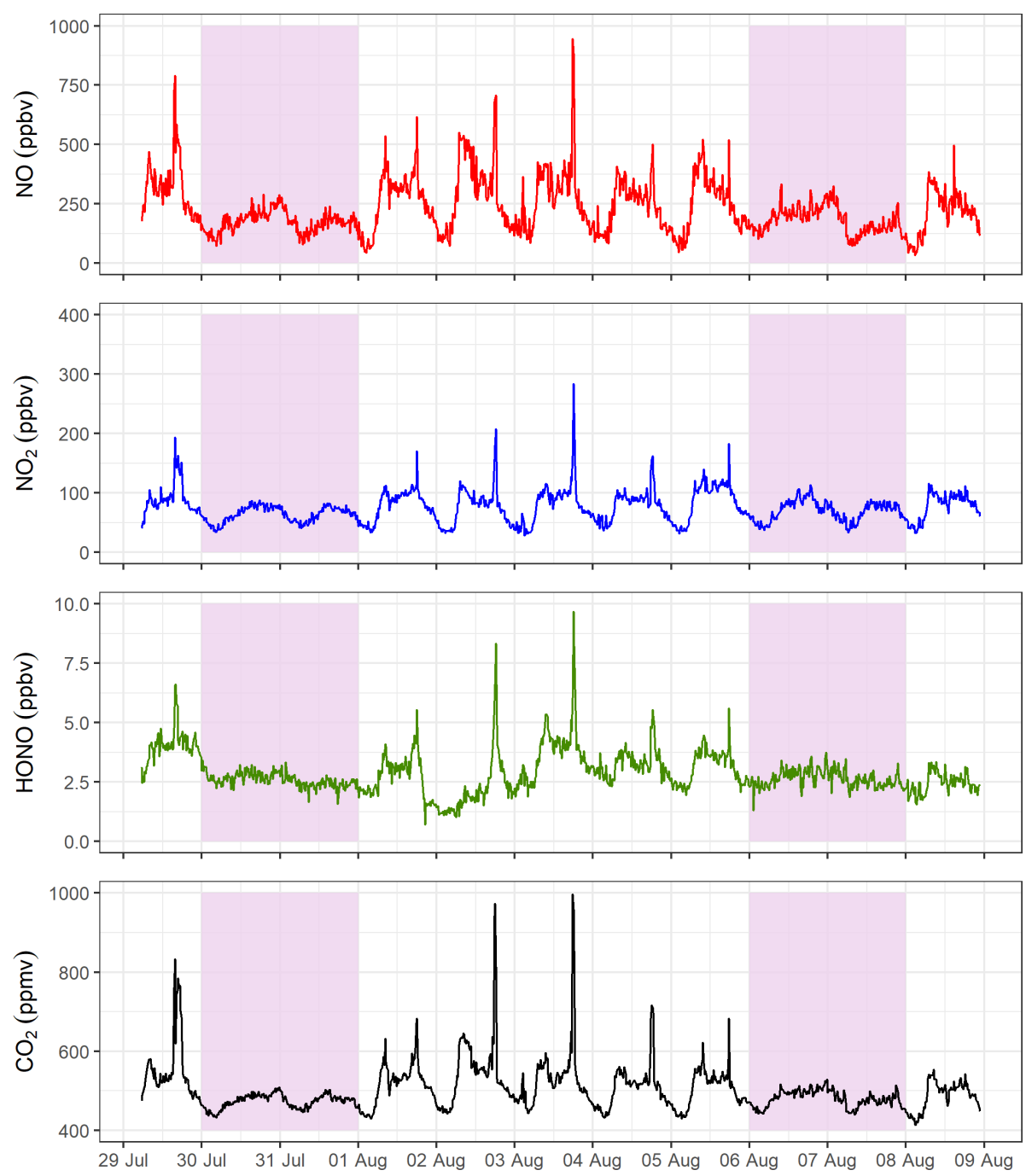

Figure 4. The 15 min averaged measurements of $\mathrm{NO}, \mathrm{NO}_{2}, \mathrm{HONO}$ and $\mathrm{CO}_{2}$ from the Queensway Tunnel between $29 \mathrm{July}$ and 8 August 2016. Shaded areas indicate the weekends. Spikes in the measured mixing ratios on weekdays are the result of traffic congestion during morning and evening rush hour periods.

The mean weekday HONO mixing ratio during the daytime (06:00 to 19:59, calculated from the $15 \mathrm{~min}$ averages) is $3.4 \pm 1.0 \mathrm{ppbv}(1 \sigma)$, which decreased to $2.4 \pm$ $0.7 \mathrm{ppbv}$ overnight. The maximum observed $15 \mathrm{~min}$ average HONO level occurred during the evening rush hour, reaching 9.7 ppbv on 3 August. Observed HONO levels in the current work are typically lower than in previous tunnel studies. Liang et al. (2017) measured a mean HONO level of $15.7 \pm 4.2 \mathrm{ppbv}$ during their study in Hong Kong, whereas Kurtenbach et al. (2001) observed peak HONO levels of $45 \mathrm{ppbv}$ in the day-time. Kirchstetter et al. (1999) only performed measurements between 16:00 and 18:00 in the Caldecott Tunnel, California, and observed a mean HONO level of $6.9 \pm 1.4 \mathrm{ppbv}$, higher than the mean level of $4.1 \pm 1.4 \mathrm{ppbv}$ for the same hours in this study. The lower levels measured in the current study may be the result of differences in vehi- cle fleet between studies as discussed further in Sect. 3.3, in combination with shorter tunnel length (Table 2) and shorter distance of our sampling point into the tunnel.

The persistence of HONO overnight is unlikely to be due to vehicle exhaust emissions, as traffic flow is low during this period, but is rather from background ambient HONO entering at the tunnel's entrance and from the heterogeneous formation of $\mathrm{HONO}$ on particles deposited onto the walls of the tunnel (Kurtenbach et al., 2001). This also suggests that vehicles were not the only source of HONO during the day, and the impact of heterogeneous HONO formation is considered in emission ratio calculations in Sect. 3.2.1.

From late evening on 1 August until mid-morning on 2 August the HONO mixing ratios are lower than otherwise observed for a weekday. Precipitation data from a nearby weather station (Fig. S3) revealed that it rained continuously 
Table 2. Comparison of $\mathrm{HONO} / \mathrm{NO}_{x}$ ratios from different tunnel studies.

\begin{tabular}{|c|c|c|c|c|c|c|c|c|}
\hline Location & $\begin{array}{l}\text { Year of } \\
\text { study }\end{array}$ & $\begin{array}{r}\text { Tunnel } \\
\text { length } \\
(\mathrm{m})\end{array}$ & $\begin{array}{r}\text { Avg. } \\
\text { vehicles per day }\end{array}$ & $\begin{array}{r}\text { Diesel } \\
\text { vehicles } \\
(\%)\end{array}$ & $\begin{array}{r}\text { Petrol } \\
\text { vehicles } \\
(\%)\end{array}$ & $\begin{array}{r}\text { Other } \\
(\%)\end{array}$ & $\begin{array}{r}\mathrm{HONO} / \mathrm{NO}_{x} \\
(\%)\end{array}$ & Reference \\
\hline $\begin{array}{l}\text { Queensway Tunnel, } \\
\text { Birmingham, UK }\end{array}$ & 2016 & 548 & 37700 & 59 & 40 & $<1$ & $\begin{array}{r}0.85 \\
(\mathrm{CI}: 0.72-1.01)\end{array}$ & This study \\
\hline $\begin{array}{l}\text { Shing Mun Tunnel, } \\
\text { Hong Kong }\end{array}$ & 2015 & 1600 & 26970 & 38 & 47 & $15^{\mathrm{a}}$ & $1.24 \pm 0.35$ & Liang et al. (2017) \\
\hline $\begin{array}{l}\text { Kiesbergtunnel, } \\
\text { Wuppertal, Germany }\end{array}$ & $\begin{array}{l}1997 / \\
1998\end{array}$ & 1100 & 22000 & $24.3^{\mathrm{b}}$ & 74.7 & 1 & $0.80 \pm 0.10$ & Kurtenbach et al. (2001) \\
\hline $\begin{array}{l}\text { Caldecott Tunnel, } \\
\text { California, USA }\end{array}$ & 1995 & 1100 & - & $<0.2$ & 99 & - & $0.29 \pm 0.05$ & Kirchstetter et al. (1996) \\
\hline
\end{tabular}

${ }^{\mathrm{a}}$ LPG fuelled. ${ }^{\mathrm{b}}$ Includes LGVs and OGVs (assumption made here that these are diesel fuelled).

from 17:00 on 1 August to 16:00 on 2 August with corresponding high relative humidity recorded inside the tunnel. It is likely that wet surfaces inside the tunnel, as a result of spray from tyres, resulted in a loss of HONO. The Henry's law constant (in water) of $\mathrm{HONO}\left(k_{\mathrm{H}}=4.8 \times\right.$ $\left.10^{-1} \mathrm{~mol} \mathrm{~m}^{-3} \mathrm{~Pa}^{-1}\right)$ is approximately 4800 times greater than that of $\mathrm{NO}_{2}\left(k_{\mathrm{H}}=9.9 \times 10^{-5} \mathrm{~mol} \mathrm{~m}^{-3} \mathrm{~Pa}^{-1}\right)$ (Sander, 2015), and therefore HONO is likely to be washed out more rapidly than $\mathrm{NO}_{2}$ on wet surfaces, resulting in a reduction in the $\mathrm{HONO} / \mathrm{NO}_{x}$ ratios. As a result, this precipitation event was excluded from the final dataset for calculation of emission ratios.

\subsection{Relative HONO emission ratios}

To determine a $\mathrm{HONO} / \mathrm{NO}_{x}$ emission ratio representative of direct exhaust emissions, corrections for both heterogeneous formation of $\mathrm{HONO}$ from $\mathrm{NO}_{2}$ and background HONO levels were considered.

\subsubsection{Heterogeneous $\mathrm{HONO}$ formation from $\mathrm{NO}_{2}$}

A number of heterogeneous reactions resulting in the formation of $\mathrm{HONO}$ have been proposed in the literature; however, the formation of $\mathrm{HONO}$ from $\mathrm{NO}_{2}$ on humid surfaces (Reaction R3) is thought to be the main pathway (Spataro and Ianniello, 2014 and references therein).

$2 \mathrm{NO}_{2(\mathrm{~g})}+\mathrm{H}_{2} \mathrm{O}_{(\mathrm{ads})} \rightarrow \mathrm{HONO}_{(\mathrm{g})}+\mathrm{HNO}_{3(\mathrm{~g})}$

The rate coefficient for Reaction (R3) ( $\left.k_{\text {het }}\right)$ is dependent on the geometric uptake coefficient of $\mathrm{NO}_{2}$ on the tunnel walls $\left(\gamma_{\text {geo }}\right)$ and is given by

$k_{\text {het }}=\frac{1}{8} \bar{\nu}_{\mathrm{NO}_{2}} \frac{S}{V} \gamma_{\text {geo }}$,

where $\bar{\nu}_{\mathrm{NO}_{2}}$ is the mean molecular velocity of $\mathrm{NO}_{2}$ and $S / V$ is the surface-to-volume ratio of the tunnel (Kurten- bach et al., 2001). Kurtenbach et al. (2001) performed laboratory experiments to measure HONO generated on tunnel wall residue to directly calculate $\gamma_{\text {geo }}$ and determined $k_{\text {het }}=3 \times 10^{-3} \mathrm{~min}^{-1}$.

The rate of formation of $\mathrm{HONO}$ from $\mathrm{NO}_{2}$ can then be calculated via Eq. (2).

$\frac{\mathrm{d}[\mathrm{HONO}]}{\mathrm{d} t}=-\frac{1}{2} \frac{\mathrm{d}\left[\mathrm{NO}_{2}\right]}{\mathrm{d} t}=k_{\mathrm{het}}\left[\mathrm{NO}_{2}\right]$,

where $\mathrm{d} t$ is the residence time of the gases in the tunnel from the entrance to the sampling point.

Kurtenbach et al. (2001) calculated that the heterogeneous conversion on the tunnel wall contributed to approximately $13 \%$ of the measured $\mathrm{HONO}$ during the day and up to $80 \%$ at night (for a maximum $\mathrm{NO}_{2}$ mixing ratio of $250 \mathrm{ppbv}$ ). This result is in contrast to measurements obtained in the Caldecott Tunnel by Kirchstetter et al. (1996), who showed that the $\mathrm{HONO} / \mathrm{NO}_{x}$ ratio did not change between the middle of the tunnel and the tunnel exit, suggesting that there was no significant formation of HONO (or deposition of HONO) on the tunnel walls in their study.

Liang et al. (2017) determined $k_{\text {het }}=1.31 \times 10^{-3} \mathrm{~min}^{-1}$ in the Shing Mun Tunnel, Hong Kong, from using an upper limit of $\gamma_{\mathrm{geo}}=10^{-6}$ as calculated by Kurtenbach et al. (2001). Using wind speed data in the tunnel to determine the residence time, Liang et al. (2017) found that the contribution of $\mathrm{HONO} / \mathrm{NO}_{x}$ from heterogeneous reactions on the tunnel walls alone was $0.04 \%$ on average. Since this value was less than the error when calculating $\mathrm{HONO} / \mathrm{NO}_{x}$ from direct emissions, the authors did not perform any corrections to their final $\mathrm{HONO} / \mathrm{NO}_{x}$ ratio. As there is no consensus in the literature about the relative contribution from tunnel walls to measured HONO, we calculated the contribution from heterogeneous HONO formation in the Queensway tunnel during the measurement period. Using Eq. (1), a geometric uptake coefficient for $\mathrm{NO}_{2}$ of $\gamma_{\text {geo }}=10^{-6}$ and the surface-tovolume ratio of the Queensway tunnel $\left(0.64 \mathrm{~m}^{-1}\right)$, we calculated $k_{\text {het }}$ to be $1.9 \times 10^{-3} \mathrm{~min}^{-1}$. 
The Kestrel anemometer used in this study logged data every $20 \mathrm{~min}$, and as a result, the wind speed measurements inside the tunnel only provide a "snap-shot" of the data and are dependent on the traffic flow. Care should be taken when using wind speed measured by an anemometer to calculate the air residence time in a tunnel. Rogak et al. (1998) compared residence times in a tunnel calculated using an $\mathrm{SF}_{6}$ tracer and anemometer data and found that the wind speed in the tunnel measured by the anemometer overestimates volumetric flow during high wind speeds and underestimates when wind speed is low, requiring a correction factor for the determination of emission factors in the tunnel. Tracer measurements were not performed during our study, and consequently a modelling approach was used to correct the wind speed data from the anemometer. As outlined below, the wall source contribution to the observed HONO was small $(\sim 5 \%$ on average) during the day-time periods used to derive our final results.

"True" wind speeds were inferred from computational fluid dynamics (CFD) modelling of $\mathrm{CO}_{2}$ profiles measured along the tunnel. After the campaign, the LI-COR $\mathrm{CO}_{2}$ instrument was installed in a van and driven repeatedly through the southbound bore of the tunnel at four different times of the day (late morning, late afternoon, evening and at night). Data recorded when the van was inside the tunnel were extracted from the $\mathrm{CO}_{2}$ time series. The timestamps of these data points were converted into distance along the tunnel using the speed of the van and the time that it entered the tunnel, as recorded by a camera mounted on the van's dashboard. The $\mathrm{CO}_{2}$ data were then averaged into $50 \mathrm{~m}$ bins along the tunnel to produce a profile of the $\mathrm{CO}_{2}$ concentration increasing with distance into the tunnel. The $\mathrm{CO}_{2}$ profiles were simulated by a CFD model which took as its inputs the tunnel's physical dimensions, the anemometer wind speed, the ANPR traffic counts and traffic composition, and emission factors from the DEFRA Emissions Factor Toolkit version (EFT v8.0.1) (DEFRA, 2017). Further information on the DEFRA EFT is provided in the supplementary material. The wind speeds that produced the optimum fits between modelled and measured $\mathrm{CO}_{2}$ profiles are shown as the crosses in Fig. S4. These wind speeds match closely with the anemometer wind speeds increased by a factor of 3.0 and they correctly capture the day- and night-time differences. The optimum CFD-inferred wind speeds at 10:00, 16:00 and 20:00 (3.4 to $\left.3.9 \mathrm{~m} \mathrm{~s}^{-1}\right)$ are also in agreement with the $3.6 \mathrm{~m} \mathrm{~s}^{-1}$ wind speed (06:00 to 23:59) in the tunnel study by Liang et al. (2017) and are consistent with the empirical correction factor produced by Rogak et al. (1998) of $\times 3.5$ for an anemometer-measured wind speed of $1.5 \mathrm{~m} \mathrm{~s}^{-1}$, applicable during much of the day-time. The results of CFD modelling of $\mathrm{CO}_{2}, \mathrm{NO}_{2}$ and $\mathrm{HONO}$ profiles measured in the Queensway tunnel will be published in a separate paper.

During the night, the measured wind speed was often below the minimum speed required to turn the anemometer's impeller $\left(<0.4 \mathrm{~m} \mathrm{~s}^{-1}\right)$ so the residence time of the air par- cel overnight is difficult to determine directly. As a result, we focus here on the heterogeneous formation of HONO in the tunnel during the day-time (see comments below, in Sect. 3.2.3, regarding use of day-time-only data to infer the fleet average emission ratios). Between 06:00 and 19:59 the mean wind speed in the tunnel was $3.9 \mathrm{~m} \mathrm{~s}^{-1}$, giving a residence time of air in the tunnel up to the sampling point of $1.86 \mathrm{~min}$. If we assume the mean residence time of $\mathrm{NO}_{2}$ emissions in the tunnel is half of this residence time (Liang et al., 2017; Pierson et al., 1978), the HONO produced from heterogeneous formation on the tunnel walls is $0.18 \mathrm{ppbv}$ for a mean daily weekday $\mathrm{NO}_{2}$ mixing ratio of $98 \mathrm{ppbv}$, which is approximately $5 \%$ of the mean measured HONO during the day. Although the mean heterogeneous contribution to HONO during the day-time is small, the heterogeneous contribution is higher $(8 \%)$ when the tunnel becomes congested and the residence time of the air in the tunnel increases. Therefore, the final HONO data used in this study were corrected for the heterogeneous HONO contribution using measured $\mathrm{NO}_{2}$ and the modelled wind speed, to better represent the direct HONO emissions in the tunnel.

\subsubsection{Background corrections for HONO, $\mathrm{NO}_{x}$ and $\mathrm{CO}_{2}$}

As vehicles travel through the tunnel, cleaner air from outside is drawn into the tunnel, which dilutes the vehicle emissions in a process known as the piston effect. To obtain direct vehicle emission measurements it is necessary to correct for this dilution by subtracting ambient background levels from the concentrations measured inside the tunnel. As no concurrent measurements were available at the tunnel entrance during this campaign, ambient $\mathrm{NO}_{x}, \mathrm{HONO}$ and $\mathrm{CO}_{2}$ data from nearby air monitoring stations were used to correct for the background levels. Hourly averaged background $\mathrm{NO}_{x}$ mixing ratios during the measurement period were taken from Acocks Green (AG), an Automatic Urban Rural Network (AURN) site located $6.9 \mathrm{~km}$ south-east of the Queensway Tunnel (http://uk-air.defra.gov.uk/, last access: 26 January 2020). The AURN station does not measure $\mathrm{HONO}$ or $\mathrm{CO}_{2}$, so data previously taken at the Birmingham Air Quality Supersite (BAQS) on the University of Birmingham campus $\left(52^{\circ} 27^{\prime} 1^{\prime \prime} \mathrm{N}, 1^{\circ} 55^{\prime} 30^{\prime \prime} \mathrm{W}\right) 3 \mathrm{~km}$ southwest of the tunnel were used in this study. $\mathrm{As}^{\mathrm{CO}_{2}}$ is well mixed within the troposphere, variability in background $\mathrm{CO}_{2}$ mixing ratios is primarily the result of a changing boundary layer height. Therefore, in this study, an average diurnal $\mathrm{CO}_{2}$ cycle measured at BAQS was used to correct for background $\mathrm{CO}_{2}$. The overnight background corrected $\mathrm{CO}_{2}$ $\left(\Delta \mathrm{CO}_{2}=\mathrm{CO}_{2 . \text { tunnel }}-\mathrm{CO}_{2 . \mathrm{bkg}}\right.$ ) levels dropped to near zero (see Fig. 5c), suggesting that the procedure was suitable. HONO on the other hand has a much shorter lifetime than $\mathrm{CO}_{2}$, and HONO mixing ratios vary depending on local sources and the availability of $\mathrm{NO}_{2}$ (Crilley et al., 2016). An average diurnal $\mathrm{HONO} / \mathrm{NO}_{x}$ cycle (Fig. S5) was calculated 
from measurements taken at BAQS between 18 March and 1 April 2015 (Singh, 2017) and applied to the background $\mathrm{NO}_{x}$ from Acocks Green to determine hourly background HONO mixing ratios (Eq. 3).

$$
[\mathrm{HONO}]_{\mathrm{bkg}}=\left[\mathrm{NO}_{x}\right]_{\mathrm{bkg}(\mathrm{AG})} \times\left(\frac{[\mathrm{HONO}]}{\left[\mathrm{NO}_{x}\right]}\right)_{\mathrm{BAQS}}
$$

Figure 5 shows the hourly time series of $\mathrm{NO}_{x}, \mathrm{HONO}$ and $\mathrm{CO}_{2}$ measured in the tunnel and the corresponding data corrected for background mixing ratios. The results show that mixing ratios measured in the tunnel were, on average, 73 and 44 times higher than the background $\mathrm{NO}_{x}$ and HONO, respectively, suggesting that direct emissions from vehicles were indeed the dominant source of these gases. Consequently, any uncertainties in the background HONO mixing ratios that were subtracted from the measured HONO have little impact on the final results. In the following sections, the final HONO dataset ( $\triangle \mathrm{HONO}$ ) is corrected for both background HONO levels and the heterogeneous HONO contribution.

\subsubsection{HONO emission ratios}

To determine the HONO to $\mathrm{NO}_{x}$ emission ratio, a reducedmajor-axis (RMA) regression (Fig. 6) was performed using the weekday hourly averaged data from 06:00 to 19:00, i.e. when there was minimal contribution from heterogeneous HONO sources and the traffic flow was high (> 1500 vehicles per hour). The slope of the regression gives an average emission ratio of $\Delta \mathrm{HONO} / \Delta \mathrm{NO}_{x}=0.85 \%$ (95\% confidence interval $=0.72 \%$ to $1.01 \%$ ) for this time period.

Figure $7 \mathrm{a}$ shows that the $\Delta \mathrm{HONO} / \Delta \mathrm{NO}_{x}$ emission ratio varies during the day, from $0.66 \%$ at $07: 00$ to $1.10 \%$ at 19:00. In this section, we explore the relationship between $\Delta \mathrm{HONO} / \Delta \mathrm{NO}_{x}$ and changes in vehicle fleet composition using information on fuel and vehicle types from the ANPR dataset. Figure 7c shows the fraction of diesel and nondiesel (petrol, LPG and electric) vehicles travelling through the Queensway tunnel during an average weekday. Between 06:00 and 17:00, the $\Delta \mathrm{HONO} / \Delta \mathrm{NO}_{x}$ ratio appears to vary closely with changes in the fraction of diesel vehicles, with both variables peaking at 10:00 when the $\Delta \mathrm{HONO} / \Delta \mathrm{NO}_{x}$ emission ratio reaches a value of $0.91 \%$ and the percentage of diesel-fuelled vehicles in the fleet reaches a maximum of $66 \%$.

The $\Delta \mathrm{HONO} / \Delta \mathrm{CO}_{2}$ ratio (Fig. $7 \mathrm{~b}$ and Table S2) also follows the change in fleet composition, with a higher ratio observed at 10:00 (3.3\%) compared to 17:00 (1.5\%). However, this may also be the result of higher $\mathrm{CO}_{2}$ emissions from petrol-fuelled vehicles compared to diesel vehicles; for example, a study of 149 passenger cars showed that $\mathrm{CO}_{2}$ emissions were $13 \%$ to $66 \%$ higher for petrol vehicles than diesel (O'Driscoll et al., 2018). Modelled emission factors from the DEFRA Emissions Factors Toolkit (EFT v8.0.1) indicate a maximum in the $\mathrm{CO}_{2}$ emissions (mg per vehicle per kilome- tre) at 17:00 (Fig. S6), in line with the $46 \%$ maximum in the non-diesel vehicle fraction at evening rush hour.

From 17:00 to $19: 00$ the relationship between the $\triangle \mathrm{HONO}$ ratios and fuel type is less clear. During this period the fraction of diesel vehicles remains almost constant; however, the $\Delta \mathrm{HONO} / \Delta \mathrm{NO}_{x}$ and $\Delta \mathrm{HONO} / \Delta \mathrm{CO}_{2}$ emission ratios both sharply increase. Analysis of the modelled $\mathrm{NO}_{x}$ and $\mathrm{CO}_{2}$ emission factors from the EFT (Fig. S6) indicate a decrease in both $\mathrm{NO}_{x}$ and $\mathrm{CO}_{2}$ emission factors from 17:00 to 19:00, which is likely to be related to the total vehicle flow and lower vehicle speed at times of peak congestion (because the fleet composition remains very similar). The EFT does not have the capability to determine a HONO emission factor, and therefore information on $\mathrm{HONO}$ emission variability with speed and vehicle flow is not available a priori. However, assuming the HONO emissions do not reduce by the same percentage after 17:00, this would lead to the increase in the observed $\Delta \mathrm{HONO} / \Delta \mathrm{NO}_{x}$ and $\Delta \mathrm{HONO} / \Delta \mathrm{CO}_{2} \mathrm{ra}-$ tios. As no conclusion can be made at this point, without additional information, we focus the analysis in the following section on the data between 06:00 and 17:00 only.

Ho et al. (2007) used Eq. (4) to determine emission factors (mg per vehicle per kilometre) for diesel- and non-dieselfuelled vehicles based on a method described by Pierson et al. (1996).

$\mathrm{EF}=\left(\mathrm{EF}_{\mathrm{DV}}-\mathrm{EF}_{\mathrm{NDV}}\right) x+\mathrm{EF}_{\mathrm{NDV}}$,

where $x$ is the fraction of diesel-fuelled vehicles, $\mathrm{EF}_{\mathrm{DV}}$ is the emission factor for diesel vehicles, $\mathrm{EF}_{\mathrm{NDV}}$ is the emission factor for non-diesel vehicles and EF is the emission factor for the mixed fleet. In this format, a linear regression of $x$ versus EF, based on Eq. (4), gives $\mathrm{EF}_{\mathrm{DV}}$ at $x=1$ and $\mathrm{EF}_{\mathrm{NDV}}$ at $x=0$.

In this study, instead of calculating emission factors, we investigated the applicability of Eq. (4) to determine $\Delta \mathrm{HONO} / \Delta \mathrm{NO}_{x}$ emission ratios for diesel $\left(\mathrm{ER}_{\mathrm{DV}}\right)$ and nondiesel ( $\mathrm{ER}_{\mathrm{NDV}}$ ) vehicles (see Fig. S7). Extrapolating the bestfit line in Fig. $\mathrm{S} 7$ to $x=1$ gives a plausible emission ratio for diesel vehicles of $\mathrm{ER}_{\mathrm{DV}}=1.35 \pm 0.50 \%$. Unfortunately, this method resulted in an unrealistically small negative emission ratio for non-diesel vehicles $\left(\mathrm{ER}_{\mathrm{NDV}}=-0.04 \pm 0.26 \%\right)$. This method may not be appropriate for the current work because the range in the fuel fraction of vehicles is small, and thus extrapolating to $x=0$ and $x=1$ resulted in large uncertainties.

An alternative approach is to determine emission ratios using a pair of simultaneous equations based on the fraction of diesel vehicles and $\Delta \mathrm{HONO} / \Delta \mathrm{NO}_{x}$ values for different hours of the day. For example, using the data as given in Table $S 2$, the equation at 17:00 is given by

$$
\frac{\Delta \mathrm{HONO}}{\Delta \mathrm{NO}_{x}}=0.73 \%=0.54 \times \mathrm{ER}_{\mathrm{DV}}+0.46 \times \mathrm{ER}_{\mathrm{NDV}} \text {. }
$$

Using another equation for a different hour (i.e. different set of fractions), the values for $\mathrm{ER}_{\mathrm{DV}}$ and $\mathrm{ER}_{\mathrm{NDV}}$ can be deter- 
(a)

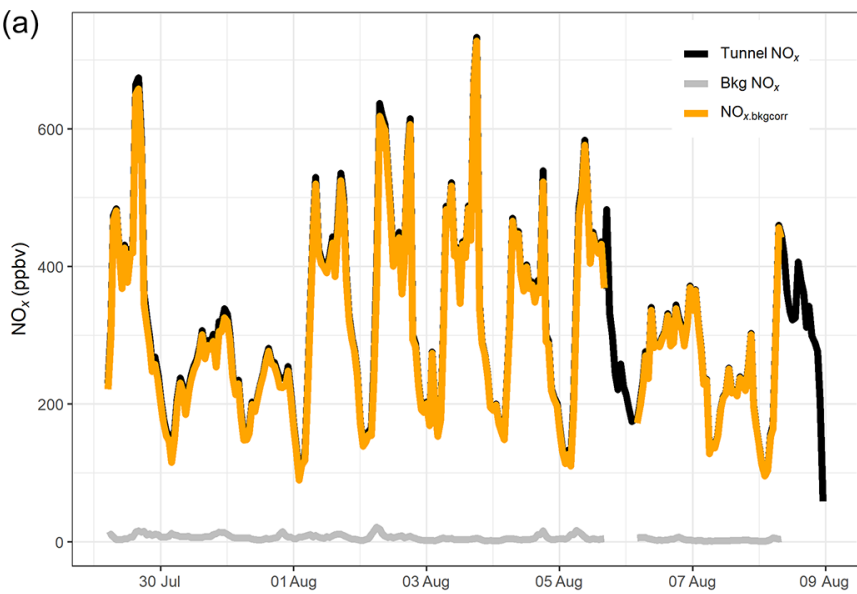

(b)

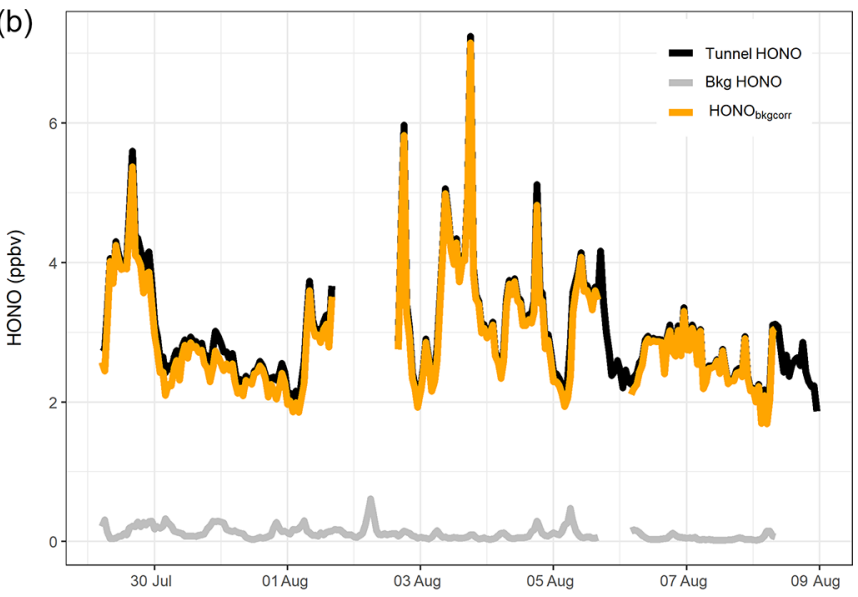

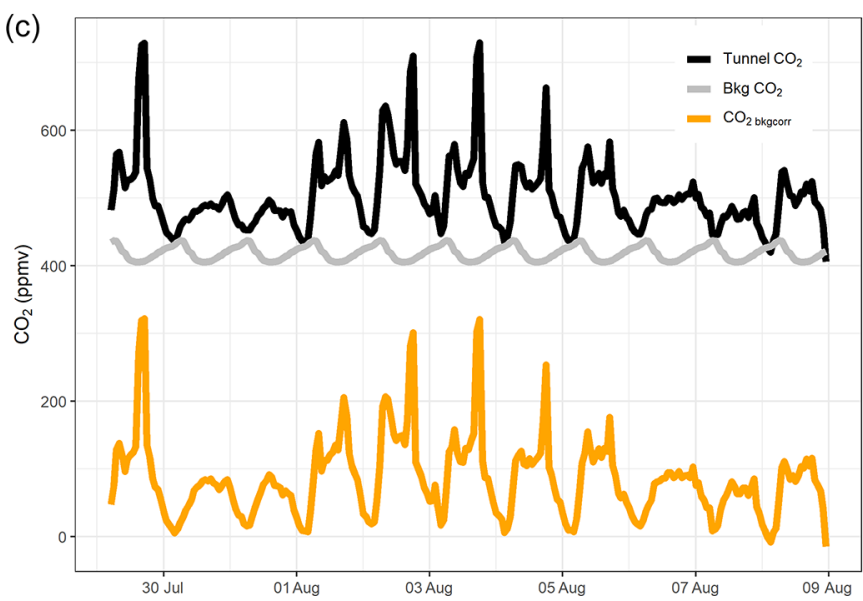

Figure 5. Hourly averaged time series (a) $\mathrm{NO}_{x}$ in the tunnel and from Acocks Green urban background station. (b) $\mathrm{HONO}$ in the tunnel and estimated background HONO. (c) $\mathrm{CO}_{2}$ in the tunnel and background $\mathrm{CO}_{2}$ measured at BAQS.

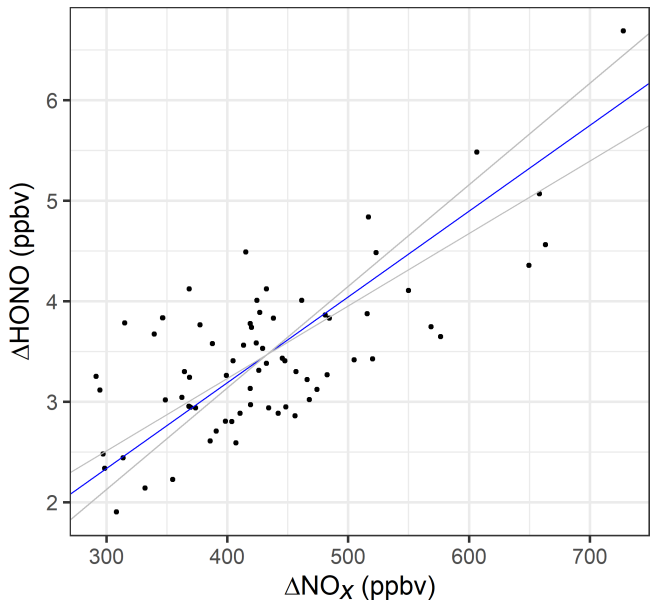

Figure 6. RMA regression for hourly averaged $\Delta \mathrm{NO}_{x}$ versus $\triangle$ HONO, for weekdays between 06:00 and 19:00. The blue line represents the RMA slope and the grey lines the $95 \%$ confidence intervals of the regression. mined. Care must be taken when interpreting these results, however, as the calculated ERs depend on the selection of pairs of measurement points and some pairs from our data resulted in negative ER values. Thus average ERs were determined using many pairs of simultaneous equations. Here we calculated the average of 10 ERs, using one set of fractions at 17:00 and a second set for each hour from 06:00 to 15:00. The data from 16:00 were not used here as there was no change in the diesel fraction between 16:00 and 17:00. The means $( \pm 1 \sigma)$ for $\mathrm{ER}_{\mathrm{DV}}$ and $\mathrm{ER}_{\mathrm{NDV}}$ are $1.04 \pm 0.47 \%$ and $0.37 \pm 0.55 \%$, respectively, suggesting that diesel-fuelled vehicles do have higher $\Delta \mathrm{HONO} / \Delta \mathrm{NO}_{x}$ ratios.

It has previously been suggested that higher $\mathrm{HONO} / \mathrm{NO}_{x}$ ratios are observed when the tunnel fleet contains a greater number of heavy-duty vehicles (Trinh et al., 2017). A similar calculation to that outlined in the previous paragraph was performed here to determine the average emission ratio for cars and for heavy-duty vehicles (goods vehicles and buses) by apportioning the observed $\Delta \mathrm{HONO} / \Delta \mathrm{NO}_{x}$ ratios between the car and heavy-duty vehicle numbers given in Table $\mathrm{S} 2$. The $\Delta \mathrm{HONO} / \Delta \mathrm{NO}_{x}$ emission ratio for heavy-duty 

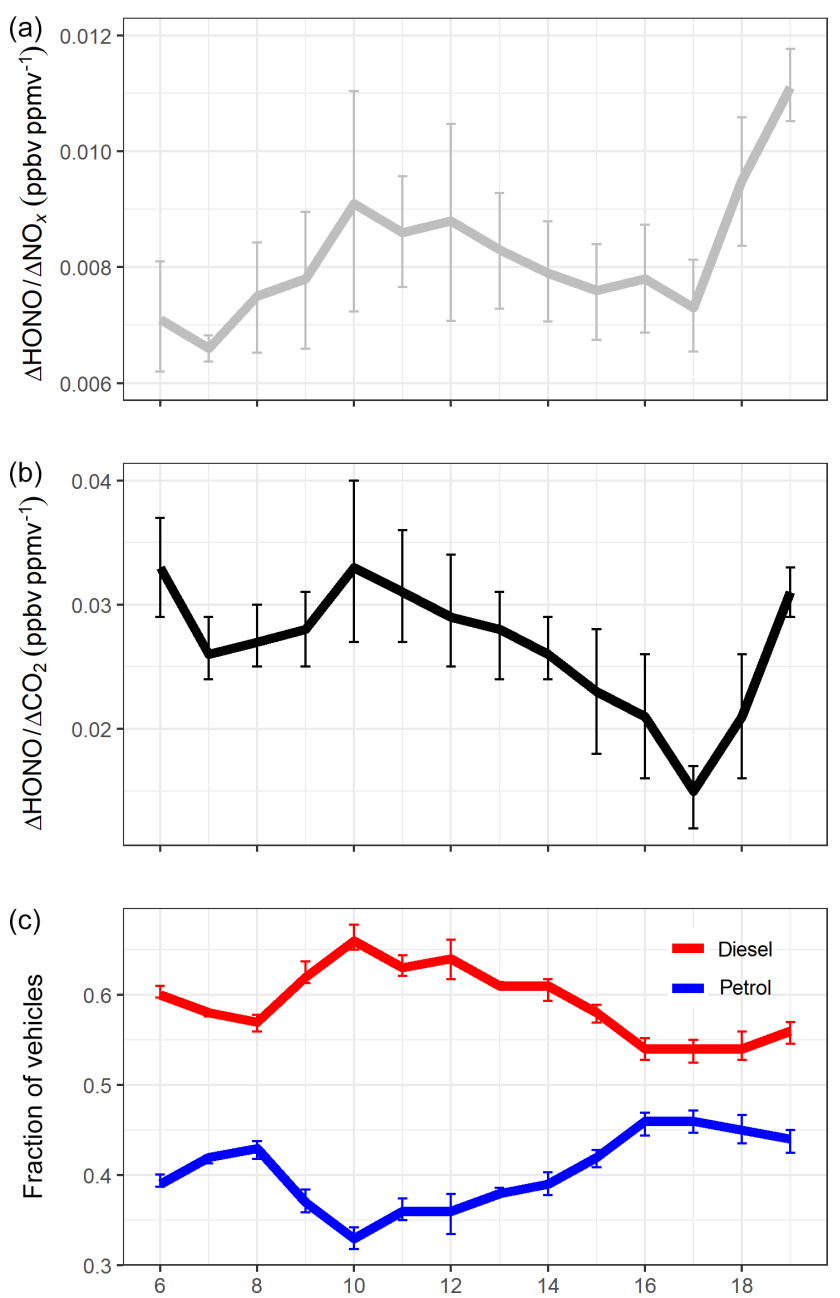

Figure 7. (a) Hourly averaged $\Delta \mathrm{HONO} / \Delta \mathrm{NO}_{x}$, (b) hourly averaged $\Delta \mathrm{HONO} / \Delta \mathrm{CO}_{2}$, and (c) fraction of diesel and non-diesel (petrol, biofuel, electric) vehicles calculated from the total petrol and diesel vehicles, for the period between 06:00 and 19:00 during weekdays. Error bars represent $1 \sigma$ standard deviation of the mean across the different days of this study.

vehicles $\left(\mathrm{ER}_{\mathrm{HD}}\right)$ is estimated to be $1.3 \pm 0.63 \%$, approximately 1.9 times higher than the ratio determined for cars $\left(\mathrm{ER}_{\mathrm{CAR}}=0.69 \pm 0.05 \%\right)$. The impact of heavy-duty vehicles on the $\mathrm{HONO} / \mathrm{NO}_{x}$ emission ratio is discussed further in Sect. 3.3.

It should be noted that the methods described above can only provide an estimate of the emission ratios for different fuel and vehicle types. In our study, the variability in the fraction of diesel vehicles and heavy-duty vehicles across the day was small, and therefore extracting emission ratios for individual vehicle types is challenging. To obtain more precise emission ratios for different engine types, a larger dataset (i.e. longer time series) and fully contemporaneous ANPR data would be required.

\subsection{Comparison of $\mathrm{HONO} / \mathrm{NO}_{x}$ emission ratios across tunnel studies}

Table 2 shows a comparison of measured $\mathrm{HONO} / \mathrm{NO}_{x}$ emission ratios from studies performed in road tunnels, along with summaries of their reported vehicle fleets. The lowest $\mathrm{HONO} / \mathrm{NO}_{x}$ ratio $(0.29 \%)$ was measured in the Caldecott tunnel, California (Kirchstetter et al., 1996). As $99 \%$ of the fleet was comprised of petrol-fuelled vehicles, the low $\mathrm{HONO} / \mathrm{NO}_{x}$ ratio is expected because the analysis in Sect. 3.2.3 above and previous dynamometer studies have both demonstrated that petrol vehicles typically emit less HONO than diesel vehicles. On the other hand, Liang et al. (2017) observed a $\mathrm{HONO} / \mathrm{NO}_{x}$ emission ratio of $1.24 \pm$ $0.35 \%$ in the Shing Mun Tunnel, Hong Kong, in 2015, approximately 1.4 times higher than in the current work despite the Queensway Tunnel having a higher proportion of diesel vehicles compared to the Shing Mun Tunnel (59\% and $38 \%$ respectively). The differences observed in the $\mathrm{HONO} / \mathrm{NO}_{x}$ emission ratio between the Shing Mun and Queensway tunnel studies may therefore be related to (1) the percentage of heavy-duty and goods vehicles within the fleet, and (2) exhaust after-treatment technologies that affect $\mathrm{NO}_{2}$ emitted directly from vehicle exhausts (known as primary $\mathrm{NO}_{2}$ ).

In addition to these two points, which are discussed further below, it should also be noted that the fleet in the Shing Mun Tunnel consisted of $15 \%$ vehicles fuelled by liquefied petroleum gas (LPG). On-road sampling of emissions from buses fuelled by diesel and LPG in Hong Kong have indicated that LPG vehicles have lower $\mathrm{NO}_{x}$ emissions when compared to diesel vehicles (Ning et al., 2012). However, as far as we are aware there have been no published studies investigating HONO emissions from LPG-fuelled vehicles, and therefore no conclusions can be made at this point regarding the impact of the LPG fleet on the observed differences in $\mathrm{HONO} / \mathrm{NO}_{x}$ ratios.

Liang et al. (2017) investigated the impact of diesel particle filters (DPFs) on HONO vehicle emissions and found that HONO emissions ratios were higher in vehicles equipped with DPFs (based on a higher $\Delta \mathrm{NO}_{2} / \Delta \mathrm{NO}_{x}$ ratio) and suggest that this may be due to HONO formation from heterogeneous reactions involving $\mathrm{NO}_{2}$ and black carbon within the filter. The diesel oxidation catalysts (DOCs) oxidize hydrocarbons and $\mathrm{CO}$ in excess oxygen over platinum-palladium catalysts; however, $\mathrm{NO}$ can also be oxidized to $\mathrm{NO}_{2}$ during this process. DPFs were mandatory for all new diesel vehicles from 2009 (Euro class V) and operate by trapping soot in the exhaust where it is then oxidized at high temperatures. To ensure the filters do not become blocked from engines that run at lower temperatures, many DPFs use catalysts to convert $\mathrm{NO}$ to $\mathrm{NO}_{2}$ to periodically oxidize the soot (He et al., 2015; Kim et al., 2010). Consequently, DOCs and DPFs both result in an increase in $\mathrm{NO}_{2}$ emitted from exhausts, which may also lead to an increase in $\mathrm{HONO}$ emissions. 
Liang et al. (2017) estimated that half of the diesel fleet in their study were buses and goods vehicles (Euro class IV and above) equipped with diesel particulate filters. In the current work less than a quarter of diesel-fuelled vehicles were goods vehicles or buses, and of those only $58 \%$ were Euro class $\mathrm{V}$ and above (i.e. with DPFs fitted). As a result, the percentage of diesel vehicles emitting high $\mathrm{NO}_{x}$ and $\mathrm{HONO}$ levels is expected to be much lower in the Queensway tunnel than the Shing Mun Tunnel, and this likely accounts for the lower $\mathrm{HONO} / \mathrm{NO}_{x}$ emission ratio we observed. In contrast, in the Kiesbergtunnel (Kurtenbach et al., 2001), medium and heavy-duty vehicles represented $12 \%$ of the fleet (6\% heavyduty trucks, $6 \%$ commercial vans), similar to the fleet in the Queensway tunnel, which may explain why the observed $\mathrm{HONO} / \mathrm{NO}_{x}$ emission ratios were so similar $(0.85 \%$ and $0.8 \%$, for the Queensway tunnel and Kiesbergtunnel studies, respectively). It should be noted that the Kiesbergtunnel study was done before the Euro III standard came into effect, so higher emissions of $\mathrm{NO}_{x}$ are expected compared to higher Euro standard vehicle classes. However, few of these vehicles in the Kiesbergtunnel would have been fitted with DOCs or DPFs, so this may have offset the amount of $\mathrm{NO}_{2}$ (and thus HONO) emitted.

Recent trend analysis studies have shown that primary $\mathrm{NO}_{2}$ has been decreasing over the last decade in the UK (Carslaw et al., 2016; Matthaios et al., 2019) and across Europe (Grange et al., 2017). For example, the mean $\mathrm{NO}_{2} / \mathrm{NO}_{x}$ emission ratio measured from ambient roadside monitoring sites in inner London has decreased from a peak value of $25 \%$ in 2009 to $15 \%$ in 2014 (Carslaw et al., 2016). Although the exact cause of the $\mathrm{NO}_{2}$ reduction is not clear, it is thought that the introduction of after-treatment technologies, such as selective catalytic reduction (SCR) installed on buses and heavy-duty vehicles, and a reduction in the use of platinum group metals in catalysts may have contributed to the observed decrease (Carslaw et al., 2016; Grange et al., 2017). With a reduction in $\mathrm{NO}_{2}$ emissions from diesel vehicles overall, a decrease in HONO may also be expected in the UK. In contrast, Wang et al. (2018) reported an increase in the $\mathrm{NO}_{2} / \mathrm{NO}_{x}$ ratio at the outlet of the Shing Mun Tunnel, from $9.5 \%$ in 2003 to $16.3 \%$ in 2015. Therefore, the higher $\mathrm{HONO} / \mathrm{NO}_{x}$ ratio observed in Hong Kong (Liang et al., 2017) compared to our current work may also be related to differences in primary $\mathrm{NO}_{2}$ emissions. It should be noted that in the study by Wang et al. (2018), $\mathrm{NO}_{2}$ was measured using a standard chemiluminescence monitor, which typically use a molybdenum converter. Molybdenum converters also convert other $\mathrm{NO}_{y}$ species, such as $\mathrm{HONO}$, resulting in an overestimation of the reported $\mathrm{NO}_{2}$. However, as the $\mathrm{HONO} / \mathrm{NO}_{x}$ ratio was only $1.24 \%$, it is unlikely that HONO has contributed to the factor of 1.7 increase in primary $\mathrm{NO}_{2}$ recorded near the Shin Mung Tunnel.

\section{Impact of HONO emissions from vehicles on total HONO measured in Birmingham}

Previous work has shown that ambient HONO has high heterogeneity when sampled close to roads (Crilley et al., 2016). Here we use the mean $\mathrm{HONO} / \mathrm{NO}_{x}$ emission factor of $0.85 \%$, determined from the tunnel measurements in Sect. 3.2.3, to investigate the contribution of direct HONO vehicle emissions to ambient HONO levels in urban and suburban areas. Measurements of $\mathrm{HONO}$ and $\mathrm{NO}_{x}$ were taken in a mobile laboratory on a return journey between Birmingham and Leicester, two cities in the UK Midlands separated by $55 \mathrm{~km}$ (straight line measurement from city centres). NO and $\mathrm{NO}_{2}$ were measured every $60 \mathrm{~s}$ by our chemiluminescence analyser fitted with a molybdenum $\mathrm{NO}_{2}$ converter (Thermo 42i-TL). As discussed in Sect. 2.3, molybdenum converters are known to result in interferences from $\mathrm{NO}_{y}$ species, and therefore the $\mathrm{NO}_{x}$ measurements presented here represent an upper limit on $\mathrm{NO}+\mathrm{NO}_{2}$ concentrations. $\mathrm{HONO}$ was measured every $5 \mathrm{~min}$ with a Long-Path Absorption Photometer (LOPAP, Model 03, QUMA). Measurement uncertainties are primarily the result of uncertainties in the calibrations and are estimated to be $5 \%$ and $10 \%$, for $\mathrm{NO}_{x}$ and $\mathrm{HONO}$, respectively. Further details regarding the measurement techniques and the driving route can be found in Crilley et al. (2016).

Figure 8 shows $\mathrm{HONO}$ and $\mathrm{NO}_{x}$ mixing ratios measured during the transect from Birmingham to Leicester and the return journey on 23 October 2015. Also shown is the directly emitted vehicular $\mathrm{HONO}\left(\mathrm{HONO}_{\mathrm{veh}}\right)$ calculated from the mean $\Delta \mathrm{HONO} / \Delta \mathrm{NO}_{x}$ emission ratio $(0.85 \%)$. For the two transects, $\mathrm{HONO}_{\text {veh }}$ contributed on average $66 \%$ to the total measured HONO. The highest contribution was observed on the M6 motorway, where $\mathrm{HONO}_{\text {veh }}$ typically accounted for $86 \%$ of the measured HONO. During the motorway segments of the journeys, the mobile laboratory was operating in "chase mode", i.e. deliberately sampling plumes from a single vehicle ahead. Therefore, it was likely the high $\mathrm{HONO}_{\text {veh }} / \mathrm{HONO}$ ratios observed on the motorway were the result of predominantly sampling vehicle emission plumes with low background contribution. The lowest $\mathrm{HONO}_{\text {veh }}$ contribution was observed around the Birmingham University campus (24\%), which is expected as traffic density was low in this area. Whilst travelling through Birmingham city centre, $\mathrm{HONO}_{\text {veh }} / \mathrm{HONO}$ increased to $70 \%$, indicating that vehicle exhaust emissions were the dominant source of HONO in this area. This value is higher than determined by Tong et al. (2016) in Beijing (48\%); however, in our study we were sampling directly on the road, whereas the site in Beijing was located in a building at the Institute of Chemistry, Chinese Academy of Sciences, and therefore significantly less influenced by direct traffic sources. This estimate neglects the differing atmospheric lifetimes of $\mathrm{HONO}$ and $\mathrm{NO}_{x}$; the longer lifetime of the latter implies that $\mathrm{HONO} / \mathrm{NO}_{x}$ ratios will fall as the air mass ages. Accordingly, estimates of the vehicular contribution derived 

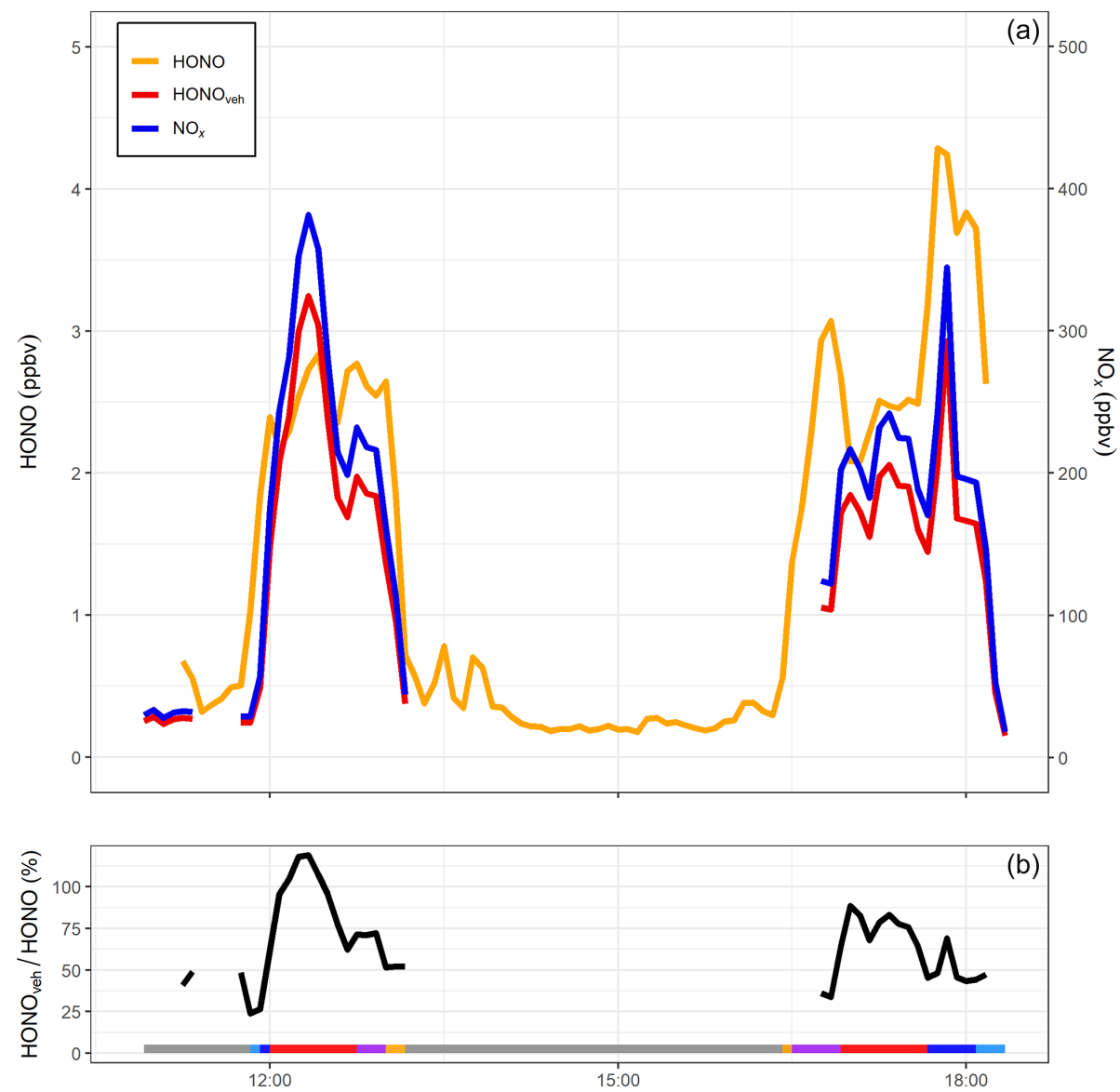

Figure 8. (a) $\mathrm{NO}_{x}, \mathrm{HONO}$ and inferred vehicle exhaust $\mathrm{HONO}$ from mobile measurements taken on 23 October 2015 along a return journey between Birmingham and Leicester (Crilley et al., 2016). (b) Ratio of vehicle-produced $\mathrm{HONO}_{\mathrm{veh}}$ to measured $\mathrm{HONO}$ (\%) for the same period. Grey shaded areas represent non-driving periods, i.e. when the mobile laboratory was parked either at the University of Birmingham or University of Leicester campus. Other colours represent measurements around the University of Birmingham campus (light blue), the A38 road through Birmingham city centre (dark blue), M6 and M69 motorways (red), Leicester Ring Road (purple) and measurements around the University of Leicester campus (orange). $\mathrm{HONO}_{\mathrm{veh}} / \mathrm{HONO}$ ratios above $100 \%$ are the result of uncertainties in the $\mathrm{HONO}$ and $\mathrm{NO}_{x}$ measurements and the $\mathrm{HONO} / \mathrm{NO}_{x}$ emission ratio.

from measurements made as close as possible to the emission source, i.e. on the roadway, as described here, will give the highest estimate of the relative importance of vehicle emissions.

Overall direct vehicle emissions can be an important source of HONO in urban areas, particularly near roads with high traffic density. Further investigation is required to quantify the impact of HONO emissions in these areas on the chemistry of the overlying atmosphere.

\section{Summary}

Measurements of $\mathrm{HONO}, \mathrm{NO}_{x}$ and $\mathrm{CO}_{2}$ were performed in a city centre road tunnel in Birmingham, UK, for 2 weeks in July and August 2016 to investigate direct HONO emissions from vehicle exhausts under real-world driving conditions. $\mathrm{HONO}$ mixing ratios peaked when $\mathrm{NO}_{x}$ and $\mathrm{CO}_{2}$ peaked during traffic congestion in the weekday evening rush hour (17:30 to 18:00), confirming that vehicle exhausts were the dominant source of HONO in the tunnel.

A HONO $/ \mathrm{NO}_{x}$ emission ratio of $0.85 \%(0.72 \%$ to $1.01 \%$ at $95 \%$ confidence interval) was determined for an average weekday fleet comprising $59 \%$ diesel-fuelled vehicles. Our value is similar to the ratio of $0.8 \%$ which is typically used in modelling studies and which was determined for a predominately petrol-fuelled fleet over 20 years ago in Germany. The results show that despite an increase in the proportion of diesel-fuelled vehicles over the past two decades in Europe, and updated emissions control technologies, the $\mathrm{HONO} / \mathrm{NO}_{x}$ emission ratio has not varied significantly. A comparison with a tunnel study in Hong Kong suggested that the $\mathrm{HONO} / \mathrm{NO}_{x}$ ratio may be less dependent on the percentage of diesel vehicles but rather the percentage of large goods 
vehicles within the fleet, and the after-treatment technologies implemented on those vehicles.

The HONO/NO$x$ emission ratio determined in this study was used to investigate the contribution of vehicle exhaust HONO to ambient HONO in Birmingham. The results show that direct vehicle emissions contribute up to $70 \%$ of the total measured HONO in the city centre. As direct HONO emissions were found to be the dominant source where traffic density is high, it is important to obtain fuel-based emission ratios which also take into account after-treatment technologies, to ensure models can accurately simulate day-time $\mathrm{OH}$ radical production rates.

In this study the focus has been primarily on HONO emissions from diesel and petrol-fuelled vehicles. However, in countries where alternative fuels such as liquefied petroleum gas (LPG) and compressed natural gas (CNG) are becoming more prevalent, in particular in the public transport sector, further investigation into HONO emissions from these fuel types is needed.

Data availability. Hourly averaged fuel type, vehicle type and emission ratios are available in the Supplement. The $15 \mathrm{~min}$ dataset from the tunnel measurements is available from the authors on request.

Supplement. The supplement related to this article is available online at: https://doi.org/10.5194/acp-20-5231-2020-supplement.

Author contributions. The study was conceived by WJB, FDP and SMB. Measurements were performed by LJK, LRC, TJA, SMB and FDP. Formal analysis performed by LJK, TJA and SMB. LJK prepared the paper with contributions from all co-authors.

Competing interests. The authors declare that they have no conflict of interest.

Acknowledgements. The authors would like to thank the staff from Amey for their help in accessing the measurement site. We would also like to thank Birmingham City Council for their input and provision of ANPR data. This work was funded by the Natural Environment Research Council (NERC) project "Sources of Nitrous Acid in the Atmospheric Boundary Layer".

Financial support. This research has been supported by the Natural Environment Research Council (grant nos. NE/M013545/1 and NE/M010554/1).

Review statement. This paper was edited by Andreas Hofzumahaus and reviewed by two anonymous referees.

\section{References}

Alicke, B., Platt, U., and Stutz, J.: Impact of nitrous acid photolysis on the total hydroxyl radical budget during the Limitation of Oxidant Production/Pianura Padana Produzione di Ozono study in Milan, J. Geophys. Res.-Atmos., 107, LOP 9-1-LOP 9-17, https://doi.org/10.1029/2000JD000075, 2002.

Ammann, M., Kalberer, M., Jost, D. T., Tobler, L., Rössler, E., Piguet, D., Gäggeler, H. W., and Baltensperger, U.: Heterogeneous production of nitrous acid on soot in polluted air masses, Nature, 395, 157-160, https://doi.org/10.1038/25965, 1998.

Arens, F., Gutzwiller, L., Baltensperger, U., Gäggeler, H. W., and Ammann, M.: Heterogeneous Reaction of $\mathrm{NO}_{2}$ Diesel Soot Particles, Environ. Sci. Technol., 35, 2191-2199, https://doi.org/10.1021/es000207s, 2001.

Aubin, D. G. and Abbatt, J. P. D.: Interaction of $\mathrm{NO}_{2}$ with hydrocarbon soot: Focus on HONO yield, surface modification, and mechanism, J. Phys. Chem. A, 111, 6263-6273, https://doi.org/10.1021/jp068884h, 2007.

Bohnenstengel, S. I., Belcher, S. E., Aiken, A., Allan, J. D., Allen, G., Bacak, A., Bannan, T. J., Barlow, J. F., Beddows, D. C. S., Bloss, W. J., Booth, A. M., Chemel, C., Coceal, O., Di Marco, C. F., Dubey, M. K., Faloon, K. H., Flemming, Z. L., Furger, M., Gietl, J. K., Graves, R. R., Green, D. C., Grimmond, C. S. B., Halios, C. H., Hamilton, J. F., Harrison, R. M., Heal, M. R., Heard, D. E., Helfter, C., Herndon, S. C., Holmes, R. E., Hopkins, J. R., Jones, A. M., Kelly, F. J., Kotthaus, S., Langford, B., Lee, J. D., Leigh, R. J., Lewis, A. C., Lidster, R. T., LopezHilfiker, F. D., McQuaid, J. B., Mohr, C., Monks, P. S., Nemitz, E., Ng, N. L., Percival, C. J., Prévôt, A. S. H., Ricketts, H. M. A., Sokhi, R., Stone, D., Thornton, J. A., Tremper, A. H., Valach, A. C., Visser, S., Whalley, L. K., Williams, L. R., Xu, L., Young, D. E., and Zotter, P.: Meteorology, air quality, and health in London: The ClearfLo project, B. Am. Meteorol. Soc., 96, 779-804, https://doi.org/10.1175/BAMS-D-12-00245.1, 2015.

Calvert, J. G., Yarwood, G., and Dunker, A. M.: An evaluation of the mechanism of nitrous acid formation in the urban atmosphere, Res. Chem. Intermediat., 20, 463-502, https://doi.org/10.1163/156856794X00423, 1994.

Carslaw, D. C. and Ropkins, K.: openair - An R package for air quality data analysis, Environ. Modell. Softw., 27-28, 52-61, https://doi.org/10.1016/j.envsoft.2011.09.008, 2012.

Carslaw, D. C., Murrells, T. P., Andersson, J., and Keenan, M.: Have vehicle emissions of primary $\mathrm{NO}_{2}$ peaked?, Faraday Discuss., 189, 439-454, https://doi.org/10.1039/C5FD00162E, 2016.

Cheng, J., Karambelkar, B., and Xie, Y.: leaflet: Create Interactive Web Maps with the JavaScript "Leaflet" Library, R package version 2.0.3, available at: https://CRAN.R-project.org/package= leaflet (last access: 28 April 2020), 2019.

Crilley, L. R., Kramer, L., Pope, F. D., Whalley, L. K., Cryer, D. R., Heard, D. E., Lee, J. D., Reed, C., and Bloss, W. J.: On the interpretation of in situ HONO observations via photochemical steady state, Faraday Discuss., 189, 191-212, https://doi.org/10.1039/c5fd00224a, 2016.

DEFRA: Emission Factors Toolkit for Vehicle Emissions, available at: https://laqm.defra.gov.uk/review-and-assessment/tools/ emissions-factors-toolkit.html (last access: 14 July 2019), 2017.

DfT: Vehicle licensing statistics: 2016, available at: https://www. gov.uk/government/statistics/vehicle-licensing-statistics-2016 (last access: 26 April 2019), 2017. 
Dunlea, E. J., Herndon, S. C., Nelson, D. D., Volkamer, R. M., San Martini, F., Sheehy, P. M., Zahniser, M. S., Shorter, J. H., Wormhoudt, J. C., Lamb, B. K., Allwine, E. J., Gaffney, J. S., Marley, N. A., Grutter, M., Marquez, C., Blanco, S., Cardenas, B., Retama, A., Ramos Villegas, C. R., Kolb, C. E., Molina, L. T., and Molina, M. J.: Evaluation of nitrogen dioxide chemiluminescence monitors in a polluted urban environment, Atmos. Chem. Phys., 7, 2691-2704, https://doi.org/10.5194/acp-7-26912007, 2007.

Elshorbany, Y. F., Kurtenbach, R., Wiesen, P., Lissi, E., Rubio, M., Villena, G., Gramsch, E., Rickard, A. R., Pilling, M. J., and K1effmann, J.: Oxidation capacity of the city air of Santiago, Chile, Atmos. Chem. Phys., 9, 2257-2273, https://doi.org/10.5194/acp9-2257-2009, 2009.

Finlayson-Pitts, B. J., Wingen, L. M., Sumner, A. L., Syomin, D., and Ramazan, K. A.: The heterogeneous hydrolysis of $\mathrm{NO}_{2}$ in laboratory systems and in outdoor and indoor atmospheres: An integrated mechanism, Phys. Chem. Chem. Phys., 5, 223-242, https://doi.org/10.1039/b208564j, 2003.

George, C., Strekowski, R. S., Kleffmann, J., Stemmler, K., and Ammann, M.: Photoenhanced uptake of gaseous $\mathrm{NO}_{2}$ on solid organic compounds: A photochemical source of HONO?, Faraday Discuss., 130, 195-210, https://doi.org/10.1039/b417888m, 2005.

Gerecke, A., Thielmann, A., Gutzwiller, L., and Rossi, M. J.: The chemical kinetics of HONO formation resulting from heterogeneous interaction of $\mathrm{NO}_{2}$ with flame soot, Geophys. Res. Lett., 25, 2453-2456, https://doi.org/10.1029/98GL01796, 1998.

Grange, S. K., Lewis, A. C., Moller, S. J., and Carslaw, D. C.: Lower vehicular primary emissions of $\mathrm{NO}_{2}$ in Europe than assumed in policy projections, Nat. Geosci., 10, 914-918, https://doi.org/10.1038/s41561-017-0009-0, 2017.

Guan, C., Li, X., Zhang, W., and Huang, Z.: Identification of nitration products during heterogeneous reaction of $\mathrm{NO}_{2}$ on soot in the dark and under simulated sunlight, J. Phys. Chem. A, 121, 482-492, https://doi.org/10.1021/acs.jpca.6b08982, 2017.

He, C., Li, J., Ma, Z., Tan, J., and Zhao, L.: High $\mathrm{NO}_{2} / \mathrm{NO}_{x}$ emissions downstream of the catalytic diesel particulate filter: An influencing factor study, J. Environ. Sci.-China, 35, 55-61, https://doi.org/10.1016/j.jes.2015.02.009, 2015.

Ho, K. F., Sai Hang Ho, S., Cheng, Y., Lee, S. C., and Zhen Yu, J.: Real-world emission factors of fifteen carbonyl compounds measured in a Hong Kong tunnel, Atmos. Environ., 41, 17471758, https://doi.org/10.1016/j.atmosenv.2006.10.027, 2007.

Huang, R. J., Yang, L., Cao, J., Wang, Q., Tie, X., Ho, K. F., Shen, Z., Zhang, R., Li, G., Zhu, C., Zhang, N., Dai, W., Zhou, J., Liu, S., Chen, Y., Chen, J., and O'Dowd, C. D.: Concentration and sources of atmospheric nitrous acid (HONO) at an urban site in Western China, Sci. Total Environ., 593-594, 165-172, https://doi.org/10.1016/j.scitotenv.2017.02.166, 2017.

Jenkin, M. E., Cox, R. A., and Williams, D. J.: Laboratory studies of the kinetics of formation of nitrous acid from the thermal reaction of nitrogen dioxide and water vapour, Atmos. Environ., 22, 487498, https://doi.org/10.1016/0004-6981(88)90194-1, 1988.

Kalberer, M., Ammann, M., Arens, F., Gäggeler, H. W., and Baltensperger, U.: Heterogeneous formation of nitrous acid (HONO) on soot aerosol particles, J. Geophys. Res.-Atmos., 104, 1382513832, https://doi.org/10.1029/1999JD900141, 1999.
Khalizov, A. F., Cruz-Quinones, M., and Zhang, R.: Heterogeneous reaction of $\mathrm{NO}_{2}$ on fresh and coated soot surfaces, J. Phys. Chem. A, 114, 7516-7524, https://doi.org/10.1021/jp1021938, 2010.

Kim, J. H., Kim, M. Y., and Kim, H. G.: $\mathrm{NO}_{2}$-assisted sort regeneration behavior in a diesel particulate filter with heavy-duty diesel exhaust gases, Numer. Heat Tr. A-Appl., 58, 725-739, https://doi.org/10.1080/10407782.2010.523293, 2010.

Kirchstetter, T. W., Harley, R. A., and Littlejohn, D.: Measurement of Nitrous Acid in Motor Vehicle Exhaust, Environ. Sci. Technol., 30, 2843-2849, https://doi.org/10.1021/es960135y, 1996.

Kirchstetter, T. W., Harley, R. A., Kreisberg, N. M., Stolzenburg, M. R., and Hering, S. V.: On-road measurement of fine particle and nitrogen oxide emissions from light- and heavy-duty motor vehicles, Atmos. Environ., 33, 2955-2968, https://doi.org/10.1016/S1352-2310(99)00089-8, 1999.

Kleffmann, J.: Daytime sources of nitrous acid (HONO) in the atmospheric boundary layer, Chem. Phys. Chem., 8, 1137-1144, https://doi.org/10.1002/cphc.200700016, 2007.

Kleffmann, J., Becker, K. H., and Wiesen, P.: Heterogeneous $\mathrm{NO}_{2}$ conversion processes on acid surfaces: Possible atmospheric implications, Atmos. Environ., 32, 2721-2729, https://doi.org/10.1016/S1352-2310(98)00065-X, 1998.

Kleffmann, J., Becker, K. H., Lackhoff, M., and Wiesen, P.: Heterogeneous conversion of $\mathrm{NO}_{2}$ on carbonaceous surfaces, Phys. Chem. Chem. Phys., 1, 5443-5450, https://doi.org/10.1039/a905545b, 1999.

Kurtenbach, R., Becker, K. H., Gomes, J. A. G., Kleffmann, J., Lörzer, J. C., Spittler, M., Wiesen, P., Ackermann, R., Geyer, A., and Platt, U.: Investigations of emissions and heterogeneous formation of HONO in a road traffic tunnel, Atmos. Environ., 35, 3385-3394, https://doi.org/10.1016/S1352-2310(01)001388, 2001.

Langridge, J. M., Gustafsson, R. J., Griffiths, P. T., Cox, R. A., Lambert, R. M., and Jones, R. L.: Solar driven nitrous acid formation on building material surfaces containing titanium dioxide: A concern for air quality in urban areas?, Atmos. Environ., 43, 51285131, https://doi.org/10.1016/j.atmosenv.2009.06.046, 2009.

Laufs, S., Cazaunau, M., Stella, P., Kurtenbach, R., Cellier, P., Mellouki, A., Loubet, B., and Kleffmann, J.: Diurnal fluxes of HONO above a crop rotation, Atmos. Chem. Phys., 17, 69076923, https://doi.org/10.5194/acp-17-6907-2017, 2017.

Lee, B. H., Wood, E. C., Herndon, S. C., Lefer, B. L., Luke, W. T., Brune, W. H., Nelson, D. D., Zahniser, M. S., and Munger, J. W.: Urban measurements of atmospheric nitrous acid: A caveat on the interpretation of the HONO photostationary state, J. Geophys. Res.-Atmos., 118, 12274-12281, https://doi.org/10.1002/2013JD020341, 2013.

Lee, J. D., Whalley, L. K., Heard, D. E., Stone, D., Dunmore, R. E., Hamilton, J. F., Young, D. E., Allan, J. D., Laufs, S., and K1effmann, J.: Detailed budget analysis of HONO in central London reveals a missing daytime source, Atmos. Chem. Phys., 16, 2747-2764, https://doi.org/10.5194/acp-16-2747-2016, 2016.

Legendre, P.: lmodel2: Model II Regression, R package version 1.7-3, availabe at: https://CRAN.R-project.org/package= lmodel2 (last access: 28 April 2020), 2018.

Lelièvre, S., Bedjanian, Y., Laverdet, G., and Le Bras, G.: Heterogeneous reaction of $\mathrm{NO}_{2}$ with hydrocar- 
bon flame soot, J. Phys. Chem. A, 108, 10807-10817, https://doi.org/10.1021/jp0469970, 2004.

Liang, Y., Zha, Q., Wang, W., Cui, L., Lui, K. H., Ho, K. F., Wang, Z., Lee, S. C., and Wang, T.: Revisiting nitrous acid (HONO) emission from on-road vehicles: A tunnel study with a mixed fleet, J. Air Waste Manage., 67, 797-805, https://doi.org/10.1080/10962247.2017.1293573, 2017.

Liu, Y., Lu, K., Ma, Y., Yang, X., Zhang, W., Wu, Y., Peng, J., Shuai, S., Hu, M., and Zhang, Y.: Direct emission of nitrous acid (HONO) from gasoline cars in China determined by vehicle chassis dynamometer experiments, Atmos. Environ., 169, 89-96, https://doi.org/10.1016/j.atmosenv.2017.07.019, 2017.

Maier, S., Tamm, A., Wu, D., Caesar, J., Grube, M., and Weber, B.: Photoautotrophic organisms control microbial abundance, diversity, and physiology in different types of biological soil crusts, ISME J., 12, 1032-1046, https://doi.org/10.1038/s41396018-0062-8, 2018.

Maljanen, M., Yli-Pirilä, P., Hytönen, J., Joutsensaari, J., and Martikainen, P. J.: Acidic northern soils as sources of atmospheric nitrous acid (HONO), Soil Biol. Biochem., 67, 94-97, https://doi.org/10.1016/j.soilbio.2013.08.013, 2013.

Matthaios, V. N., Kramer, L. J., Sommariva, R., Pope, F. D., and Bloss, W. J.: Investigation of vehicle cold start primary $\mathrm{NO}_{2}$ emissions inferred from ambient monitoring data in the UK and their implications for urban air quality, Atmos. Environ., 199, 402-414, https://doi.org/10.1016/j.atmosenv.2018.11.031, 2019.

Meusel, H., Tamm, A., Kuhn, U., Wu, D., Leifke, A. L., Fiedler, S., Ruckteschler, N., Yordanova, P., Lang-Yona, N., Pöhlker, M., Lelieveld, J., Hoffmann, T., Pöschl, U., Su, H., Weber, B., and Cheng, Y.: Emission of nitrous acid from soil and biological soil crusts represents an important source of HONO in the remote atmosphere in Cyprus, Atmos. Chem. Phys., 18, 799-813, https://doi.org/10.5194/acp-18-799-2018, 2018.

Michoud, V., Kukui, A., Camredon, M., Colomb, A., Borbon, A., Miet, K., Aumont, B., Beekmann, M., Durand-Jolibois, R., Perrier, S., Zapf, P., Siour, G., Ait-Helal, W., Locoge, N., Sauvage, S., Afif, C., Gros, V., Furger, M., Ancellet, G., and Doussin, J. F.: Radical budget analysis in a suburban European site during the MEGAPOLI summer field campaign, Atmos. Chem. Phys., 12, 11951-11974, https://doi.org/10.5194/acp-12-119512012, 2012.

Michoud, V., Colomb, A., Borbon, A., Miet, K., Beekmann, M., Camredon, M., Aumont, B., Perrier, S., Zapf, P., Siour, G., AitHelal, W., Afif, C., Kukui, A., Furger, M., Dupont, J. C., Haeffelin, M., and Doussin, J. F.: Study of the unknown HONO daytime source at a European suburban site during the MEGAPOLI summer and winter field campaigns, Atmos. Chem. Phys., 14, 2805-2822, https://doi.org/10.5194/acp-14-2805-2014, 2014.

Monge, M. E., D’Anna, B., Mazri, L., Giroir-Fendler, A., Ammann, M., Donaldson, D. J., and George, C.: Light changes the atmospheric reactivity of soot, P. Natl. Acad. Sci. USA, 107, 66056609, https://doi.org/10.1073/pnas.0908341107, 2010.

Nakashima, Y. and Kajii, Y.: Determination of nitrous acid emission factors from a gasoline vehicle using a chassis dynamometer combined with incoherent broadband cavity-enhanced absorption spectroscopy, Sci. Total Environ., 575, 287-293, https://doi.org/10.1016/j.scitotenv.2016.10.050, 2017.

Ning, Z., Wubulihairen, M., and Yang, F.: PM, $\mathrm{NO}_{x}$ and butane emissions from on-road vehicle fleets in Hong Kong and their implications on emission control policy, Atmos. Environ., 61, 265-274, https://doi.org/10.1016/j.atmosenv.2012.07.047, 2012.

O’Driscoll, R., Stettler, M. E. J., Molden, N., Oxley, T., and ApSimon, H. M.: Real world $\mathrm{CO}_{2}$ and $\mathrm{NO}_{2}$ emissions from 149 Euro 5 and 6 diesel, gasoline and hybrid passenger cars, Sci. Total Environ., 621, 282-290, https://doi.org/10.1016/j.scitotenv.2017.11.271, 2018.

Oswald, R., Behrendt, T., Ermel, M., Wu, D., Su, H., Cheng, Y., Breuninger, C., Moravek, A., Mougin, E., Delon, C., Loubet, B., Pommerening-Röser, A., Sörgel, M., Pöschl, U., Hoffmann, T., Andreae, M. O., Meixner, F. X., and Trebs, I.: HONO emissions from soil bacteria as a major source of atmospheric reactive nitrogen, Science, 341, 1233-1235, https://doi.org/10.1126/science.1242266, 2013.

Pierson, W. R., Brachaczek, W. W., Hammerle, R. H., McKee, D. E., and Butler, J. W.: Sulfate Emissions from Vehicles on the Road, J. Air Pollut. Control Assoc., 28, 123-132, https://doi.org/10.1080/00022470.1978.10470579, 1978.

Pierson, W. R., Gertler, A. W., Robinson, N. F., Sagebiel, J. C., Zielinska, B., Bishop, G. A., Stedman, D. H., Zweidinger, R. B., and Ray, W. D.: Real-world automotive emissions - summary of studies in the Fort McHenry and Tuscarora Mountain Tunnels, Atmos. Environ., 30, 2233-2256, https://doi.org/10.1016/13522310(95)00276-6, 1996.

Pitts, J. N., Biermann, H. W., Winer, A. M., and Tuazon, E. C.: Spectroscopic identification and measurement of gaseous nitrous acid in dilute auto exhaust, Atmos. Environ., 18, 847-854, https://doi.org/10.1016/0004-6981(84)90270-1, 1984.

Qin, M., Xie, P., Su, H., Gu, J., Peng, F., Li, S., Zeng, L., Liu, J., Liu, W., and Zhang, Y.: An observational study of the HONO-NO $\mathrm{NO}_{2}$ coupling at an urban site in Guangzhou City, South China, Atmos. Environ., 43, 5731-5742, https://doi.org/10.1016/j.atmosenv.2009.08.017, 2009.

Rappenglück, B., Lubertino, G., Alvarez, S., Golovko, J., Czader, B., and Ackermann, L.: Radical precursors and related species from traffic as observed and modeled at an urban highway junction, J. Air Waste Manage., 63, 1270-1286, https://doi.org/10.1080/10962247.2013.822438, 2013.

$\mathrm{R}$ Core Team: A language and environment for statistical computing, R Foundation for Statistical Computing, Vienna, Austria, available at: https://www.R-project.org/ (last access: 28 April 2020), 2019.

Reed, C., Evans, M. J., Crilley, L. R., Bloss, W. J., Sherwen, T., Read, K. A., Lee, J. D., and Carpenter, L. J.: Evidence for renoxification in the tropical marine boundary layer, Atmos. Chem. Phys., 17, 4081-4092, https://doi.org/10.5194/acp17-4081-2017, 2017.

Rhead, M., Gurney, R., Ramalingam, S., and Cohen, N.: Accuracy of automatic number plate recognition (ANPR) and real world UK number plate problems, in: Proceedings of the 46th IEEE International Carnahan Conference on Security Technology, Institute of Electrical and Electronics Engineers (IEEE), 286-291, https://doi.org/10.1109/CCST.2012.6393574, 2012.

Richard, C., Gordon, I. E., Rothman, L. S., Abel, M., Frommhold, L., Gustafsson, M., Hartmann, J. M., Hermans, C., Lafferty, W. J., Orton, G. S., Smith, K. M., and Tran, H.: New section of the HITRAN database: Collision-induced absorption (CIA), J. Quant. Spectrosc. Ra., 113, 1276-1285, https://doi.org/10.1016/j.jqsrt.2011.11.004, 2012. 
Rogak, S. N., Green, S. I., and Pott, U.: Use of tracer gas for direct calibration of emission-factor measurements in a traffic tunnel, J. Air Waste Manage., 48, 545-552, https://doi.org/10.1080/10473289.1998.10463707, 1998.

Romanias, M. N., Bedjanian, Y., Zaras, A. M., Andrade-Eiroa, A., Shahla, R., Dagaut, P., and Philippidis, A.: Mineral oxides change the atmospheric reactivity of soot: $\mathrm{NO}_{2}$ uptake under dark and UV irradiation conditions, J. Phys. Chem. A, 117, 12897-12911, https://doi.org/10.1021/jp407914f, 2013.

Sander, R.: Compilation of Henry's law constants (version 4.0) for water as solvent, Atmos. Chem. Phys., 15, 4399-4981, https://doi.org/10.5194/acp-15-4399-2015, 2015.

Singh, A.: Quantifying the effect of atmospheric pollution and meteorology on visibility and tropospheric chemistry, University of Birmingham, available at: https://etheses.bham.ac.uk//id/eprint/ 7828/ (last access: 29 April 2019), 2017.

Spataro, F. and Ianniello, A.: Sources of atmospheric nitrous acid: State of the science, current research needs, and future prospects, J. Air Waste Manage., 64, 1232-1250, https://doi.org/10.1080/10962247.2014.952846, 2014.

Stadler, D. and Rossi, M. J.: The reactivity of $\mathrm{NO}_{2}$ and HONO on flame soot at ambient temperature: The influence of combustion conditions, Phys. Chem. Chem. Phys., 2, 5420-5429, https://doi.org/10.1039/b005680o, 2000.

Stemmler, K., Ammann, M., Donders, C., Kleffmann, J., and George, C.: Photosensitized reduction of nitrogen dioxide on humic acid as a source of nitrous acid, Nature, 440, 195-198, https://doi.org/10.1038/nature04603, 2006.

Stutz, J., Kim, E. S., Platt, U., Bruno, P., Perrino, C., and Febo, A.: UV-visible absorption cross sections of nitrous acid, J. Geophys. Res.-Atmos., 105, 14585-14592, https://doi.org/10.1029/2000JD900003, 2000.

Stutz, J., Alicke, B., and Neftel, A.: Nitrous acid formation in the urban atmosphere: Gradient measurements of $\mathrm{NO}_{2}$ and HONO over grass in Milan, Italy, J. Geophys. Res., 107, 8192, https://doi.org/10.1029/2001JD000390, 2002.

Stutz, J., Alicke, B., Ackermann, R., Geyer, A., Wang, S., White, A. B., Williams, E. J., Spicer, C. W., and Fast, J. D.: Relative humidity dependence of HONO chemistry in urban areas, J. Geophys. Res., 109, D03307, https://doi.org/10.1029/2003JD004135, 2004.

Su, H., Cheng, Y., Oswald, R., Behrendt, T., Trebs, I., Meixner, F. X., Andreae, M. O., Cheng, P., Zhang, Y., and Pöschl, U.: Soil nitrite as a source of atmospheric $\mathrm{HONO}$ and $\mathrm{OH}$ radicals, Science, 333, 1616-1618, https://doi.org/10.1126/science.1207687, 2011.

Thalman, R., Baeza-Romero, M. T., Ball, S. M., Borrás, E., Daniels, M. J. S., Goodall, I. C. A., Henry, S. B., Karl, T., Keutsch, F. N., Kim, S., Mak, J., Monks, P. S., Muñoz, A., Orlando, J., Peppe, S., Rickard, A. R., Ródenas, M., Sánchez, P., Seco, R., Su, L., Tyndall, G., Vázquez, M., Vera, T., Waxman, E., and Volkamer, R.: Instrument intercomparison of glyoxal, methyl glyoxal and $\mathrm{NO}_{2}$ under simulated atmospheric conditions, Atmos. Meas. Tech., 8 , 1835-1862, https://doi.org/10.5194/amt-8-1835-2015, 2015.

Tong, S., Hou, S., Zhang, Y., Chu, B., Liu, Y., He, H., Zhao, P., and Ge, M.: Exploring the nitrous acid (HONO) formation mechanism in winter Beijing: Direct emissions and heterogeneous production in urban and suburban areas, Faraday Discuss., 189, 213230, https://doi.org/10.1039/c5fd00163c, 2016.
Trinh, H. T., Imanishi, K., Morikawa, T., Hagino, H., and Takenaka, N.: Gaseous nitrous acid (HONO) and nitrogen oxides $\left(\mathrm{NO}_{x}\right)$ emission from gasoline and diesel vehicles under realworld driving test cycles, J. Air Waste Manage., 67, 412-420, https://doi.org/10.1080/10962247.2016.1240726, 2017.

Vandaele, A. C., Hermans, C., Simon, P. C., Carleer, M., Colin, R., and Coquartii, B.: Measurements of the $\mathrm{NO}_{2}$ absorption cross-section from $42000 \mathrm{~cm}^{-1}$ to $10000 \mathrm{~cm}^{-1}(238-1000 \mathrm{~nm})$ at $220 \mathrm{~K}$ and $294 \mathrm{~K}$, J. Quant. Spectrosc. Ra., 59, 171-184, 1998.

Vandenboer, T. C., Markovic, M. Z., Sanders, J. E., Ren, X., Pusede, S. E., Browne, E. C., Cohen, R. C., Zhang, L., Thomas, J., Brune, W. H., and Murphy, J. G.: Evidence for a nitrous acid (HONO) reservoir at the ground surface in Bakersfield, CA, during CalNex 2010, J. Geophys. Res., 119, 9093-9106, https://doi.org/10.1002/2013JD020971, 2014.

Villena, G., Wiesen, P., Cantrell, C. A., Flocke, F., Fried, A., Hall, S. R., Hornbrook, R. S., Knapp, D., Kosciuch, E., Mauldin, R. L., McGrath, J. A., Montzka, D., Richter, D., Ullmann, K., Walega, J., Weibring, P., Weinheimer, A., Staebler, R. M., Liao, J., Huey, L. G., and Kleffmann, J.: Nitrous acid (HONO) during polar spring in Barrow, Alaska: A net source of $\mathrm{OH}$ radicals?, J. Geophys. Res.-Atmos., 116, 1-12, https://doi.org/10.1029/2011JD016643, 2011.

Villena, G., Bejan, I., Kurtenbach, R., Wiesen, P., and Kleffmann, J.: Interferences of commercial $\mathrm{NO}_{2}$ instruments in the urban atmosphere and in a smog chamber, Atmos. Meas. Tech., 5, 149-159, https://doi.org/10.5194/amt-5-149-2012, 2012.

Vogel, B., Vogel, H., Kleffmann, J., and Kurtenbach, R.: Measured and simulated vertical profiles of nitrous acid - Part II. Model simulations and indications for a photolytic source, Atmos. Environ., 37, 2957-2966, https://doi.org/10.1016/S13522310(03)00243-7, 2003.

Wang, J., Zhang, X., Guo, J., Wang, Z., and Zhang, M.: Observation of nitrous acid (HONO) in Beijing, China: Seasonal variation, nocturnal formation and daytime budget, Sci. Total Environ., 587-588, 350-359, https://doi.org/10.1016/j.scitotenv.2017.02.159, 2017.

Wang, X., Ho, K. F., Chow, J. C., Kohl, S. D., Chan, C. S., Cui, L., Lee, S. cheng F., Chen, L. W. A., Ho, S. S. H., Cheng, Y., and Watson, J. G.: Hong Kong vehicle emission changes from 2003 to 2015 in the Shing Mun Tunnel, Aerosol Sci. Tech., 52, 10851098, https://doi.org/10.1080/02786826.2018.1456650, 2018.

Weber, B., Wu, D., Tamm, A., Ruckteschler, N., RodríguezCaballero, E., Steinkamp, J., Meusel, H., Elbert, W., Behrendt, T., Sörgel, M., Cheng, Y., Crutzen, P. J., Su, H., and Pöschl, U.: Biological soil crusts accelerate the nitrogen cycle through large NO and HONO emissions in drylands, P. Natl. Acad. Sci. USA, 112, 15384-15389, https://doi.org/10.1073/pnas.1515818112, 2015.

Wickham, H.: ggplot2: Elegant Graphics for Data Analysis, Springer-Verlag, New York, 2016.

Xu, Z., Wang, T., Wu, J., Xue, L., Chan, J., Zha, Q., Zhou, S., Louie, P. K. K., and Luk, C. W. Y.: Nitrous acid (HONO) in a polluted subtropical atmosphere: Seasonal variability, direct vehicle emissions and heterogeneous production at ground surface, Atmos. Environ., 106, 100-109, https://doi.org/10.1016/j.atmosenv.2015.01.061, 2015.

Yang, Q., Su, H., Li, X., Cheng, Y., Lu, K., Cheng, P., Gu, J., Guo, S., Hu, M., Zeng, L., Zhu, T., and Zhang, Y.: Daytime HONO for- 
mation in the suburban area of the megacity Beijing, China, Sci. China Chem., 57, 1032-1042, https://doi.org/10.1007/s11426013-5044-0, 2014.

Ye, C., Zhang, N., Gao, H., and Zhou, X.: Photolysis of Particulate Nitrate as a Source of $\mathrm{HONO}$ and $\mathrm{NO}_{x}$, Environ. Sci. Technol., 51, 6849-6856, https://doi.org/10.1021/acs.est.7b00387, 2017.
Zhou, X., Zhang, N., Teravest, M., Tang, D., Hou, J., Bertman, S., and Stevens, P. S.: Nitric acid photolysis on forest canopy surface as a source for tropospheric nitrous acid, Nat. Geosci., 4, 440443, https://doi.org/10.1038/ngeo1164, 2011. 